
\title{
R Research Soure \\ Do Energy Consumption and Environmental Quality Enhance Subjective Wellbeing in G20 Countries?
}

Neha Kumari ( $\square$ nk24@iitbbs.ac.in )

Indian Institute of Technology Bhubaneswar https://orcid.org/0000-0001-5327-5321

\section{Pushp Kumar}

Indian Institute of Technology Bhubaneswar

Naresh Chandra Sahu

Indian Institute of Technology Bhubaneswar

\section{Research Article}

Keywords: G20 Countries, Subjective Wellbeing, PCSE, Newey West Method, Renewable Energy Consumption, Non-renewable Energy Consumption, $\mathrm{CO} 2$ Emissions

Posted Date: May 5th, 2021

DOl: https://doi.org/10.21203/rs.3.rs-480646/v1

License: @ (i) This work is licensed under a Creative Commons Attribution 4.0 International License.

Read Full License 


\title{
Do Energy Consumption and Environmental Quality Enhance Subjective Wellbeing in G20
} Countries?

\author{
Neha Kumari (Corresponding Author) \\ $\mathrm{PhD}$ Scholar \\ School of Humanities, Social Sciences, and Management \\ Indian Institute of Technology Bhubaneswar, Odisha 752050, India \\ Email Id: nk24@iitbbs.ac.in \\ ORCID ID: 0000-0001-5327-5321 \\ Pushp Kumar \\ $\mathrm{PhD}$ Scholar \\ School of Humanities, Social Sciences, and Management \\ Indian Institute of Technology Bhubaneswar, Odisha 752050, India \\ Email Id: pk27@iitbbs.ac.in \\ ORCID ID: 0000-0002-2355-1871 \\ Dr. Naresh Chandra Sahu \\ Assistant Professor \\ School of Humanities, Social Sciences, and Management \\ Indian Institute of Technology Bhubaneswar, Odisha 752050, India \\ Email Id: naresh@iitbbs.ac.in \\ ORCID ID: 0000-0002-4013-1801
}

\begin{abstract}
G20 countries are responsible for more than $80 \%$ of global energy consumption and the largest emitter of $\mathrm{CO}_{2}$ in the world. Literature related to the energy consumption-environmental quality-subjective wellbeing nexus is limited and lacks consensus. This paper analyses the impact of energy consumption and environmental quality on subjective wellbeing in G20 countries from 2006 to 2019 using a panel corrected standard error (PCSE) panel model. Cantril life ladder data is used as a proxy of subjective wellbeing. For robustness, the Newey-West standard error model is used. The findings reveal that renewable energy consumption and improved environmental quality, i.e. lesser carbon emissions enhance subjective wellbeing in G20 countries. In contrast, non-renewable energy consumption degrades subjective wellbeing. Moreover, the study also finds a bidirectional causality between renewable energy consumption, non-renewable energy consumption, and economic growth. The policymakers of these countries should encourage renewable energy production and its consumption to reduce carbon emissions for conserving the environment and enhancing their people's subjective wellbeing.

Keywords: G20 Countries; Subjective Wellbeing; PCSE, Newey West Method; Renewable Energy Consumption; Non-renewable Energy Consumption; $\mathrm{CO}_{2}$ Emissions
\end{abstract}




\section{Abstract}

G20 countries are responsible for more than $80 \%$ of global energy consumption and the largest emitter of $\mathrm{CO}_{2}$ in the world. Literature related to the energy consumption-environmental quality-subjective wellbeing nexus is limited and lacks consensus. This paper analyses the impact of energy consumption and environmental quality on subjective wellbeing in G20 countries from 2006 to 2019 using a panel corrected standard error (PCSE) panel model. Cantril life ladder data is used as a proxy of subjective wellbeing. For robustness, the Newey-West standard error model is used. The findings reveal that renewable energy consumption and improved environmental quality, i.e. lesser carbon emissions enhance subjective wellbeing in G20 countries. In contrast, non-renewable energy consumption degrades subjective wellbeing. Moreover, the study also finds a bidirectional causality between renewable energy consumption, non-renewable energy consumption, and economic growth. The policymakers of these countries should encourage renewable energy production and its consumption to reduce carbon emissions for conserving the environment and enhancing their people's subjective wellbeing.

Keywords: G20 Countries; Subjective Wellbeing; PCSE, Newey West Method; Renewable Energy Consumption; Non-renewable Energy Consumption; $\mathrm{CO}_{2}$ Emissions

\section{Introduction}

According to the United Nations Environment Programme (2020), despite the cut in carbon emissions due to the COVID-19, the world is heading towards a temperature rise above $3^{\circ} \mathrm{C}$. The non- $\mathrm{CO}_{2}$ components of greenhouse gases (GHGs) such as methane $\left(\mathrm{CH}_{4}\right)$ and nitrous oxide $\left(\mathrm{N}_{2} \mathrm{O}\right)$ continued to increase in 2020. Executive Director Inger Andersen of United Nations Environment Programme (UNEP) recently urged for the immediate need of reducing emissions; otherwise, the goal to reach $1.5^{\circ} \mathrm{C}$ by 2030 will only be a dream (UNEP, 2020). This rise of $3^{\circ} \mathrm{C}$ in global temperatures could result in catastrophic weather-related events, ozone depletion, and ecosystem degradation, which is a severe threat to humankind.

It is widely evident from the literature that massive energy consumption activities are responsible for the increasing GHG emissions (Hao et al., 2015; Khan et al., 2014; Sarkodie \& Strezov, 2019) and climate change (MacKay, 2008). The use of cleaner and sustainable energy in both production and consumption is required to meet long-run energy and climate goals (IEA, 2020). Therefore 37 countries have committed to shift from nonrenewable to renewable energy consumption in the Doha Amendment, $2^{\text {nd }}$ commitment period (2013-2020).

G20 countries account for two-thirds of the world population and have more than $80 \%$ of energy demand (Rogelj et al., 2016). It is a global body comprising the 20 largest economies, and consumes $95 \%$ of the world's coal, more than $70 \%$ of its oil and gas, and is responsible for $85 \%$ of global investment in renewables (Goldthau, 2017). The G20 comprises Argentina, Australia, Brazil, Canada, China, EU, France, Germany, India, Indonesia, Italy, Japan, Mexico, Russia, Saudi Arabia, South Africa, South Korea, Turkey, UK, and the USA. These countries have experienced energy-led growth and are under continuous pressure for $\mathrm{CO}_{2}$ mitigations. For overcoming the Paris 
energy-saving technologies (Qiao et al. 2019). Many G20 countries like Germany, Italy, France, the UK, the United States, Canada and Japan, and the EU have experienced high growth rates in renewable energy production and reduction in fossil fuel consumption.

The purpose of energy consumption in a economy is to improve the wellbeing of humankind. One of the goals of the Sustainable Development Goal (SDGs) is to ensure universal access to affordable, reliable, and modern energy by 2030. These goals reflect the significance of energy services for meeting basic needs and improving wellbeing (Kalt et al., 2019). Indeed, higher energy consumption has reduced drudgery, increased productivity, and provided a comfortable life. Alam et al. (1991) have found a positive association of electricity consumption and physical quality of life (PQLI) with the per capita electrical energy consumption in 112 countries. Residential energy consumption positively contributes to household living standards through lighting, cooking, heating, and cooling and promotes wellbeing (Welsch and Biermann, 2019). In the Nagasaki city of Japan, Liu et al. (2016) have investigated the link between energy consumption and quality of life (QOL). Energy consumption in the form of demand for car trips and public transport trips raises the quality of life. Shobande (2020) has found a positive impact of energy use on infant mortality rate in the panel of 23 African countries. Liu and Matsushina (2019) have used HDI as a proxy of QOL and found that HDI improves with the changes in energy quality in the OECD and non-OECD countries. Better access to energy promotes economic growth and human development together and increases the pace of achieving the target of SDGs (Ouedraogo, 2013). Niu et al. (2013) have found that countries with a higher level of income and higher per capita energy consumption have attained a higher level of human development. Wang (2020) have found a positive link between renewable energy consumption and human development in BRICS countries during 1990-2016. Renewable energy production helps the countries to achieve higher HDI via enhanced economic development (Kazar and Kazar, 2014).

But the higher level of pollution, GHG emissions, and climate change brought by rampant energy consumption have threatened the Subjective Wellbeing (SWB) of people worldwide. SWB is used to measure the wellbeing of people based on subjective evaluations of a person's own lives (Diener, 2000). It includes both positive (happiness), negative emotions (sadness, anxiety, and stress), and life satisfaction. In economics, only the revealed preferences in the form of choices have been given importance rather than the psychological aspect, i.e., selfreported preference (Case and Deaton, 2015). After the emergence of Bhutan's Gross national happiness index (GNH) and the Easterlin Paradox debate, economists have started considering SWB. Stiglitz et al. (2009) have recommended countries to adopt the subjective determinants of wellbeing because it can better understand people's lives beyond income and material consumption. The happiness ranking of G20 countries is presented in Figure 1.

Insert [Figure 1]

Deterioration of environmental quality has adversely affected the mental health and subjective wellbeing of the people. Rehdanz and Maddison (2005) established that weather changes caused by global warming has an adverse effect on people's happiness ${ }^{1}$. Welsch (2006) shows that air pollution has a strong negative impact on subjective wellbeing. Ferrer-i-Carbonell and Gowdy (2007) obtained a negative coefficient for concern about ozone pollution and an individual's wellbeing. In a similar study, Cuñado and Gracia (2013) explored the relationship between air

\footnotetext{
${ }^{1}$ In this paper, Happiness and life satisfaction (LS) are used interchangeably as a proxy of SWB.
} 
114 dioxide, nitrous oxide, and airborne particulate matter (PM) is negatively related to happiness. Similarly, Spanish people are unhappy during high temperatures and high precipitation. Tiwari (2014) indicated that $\mathrm{CO}_{2}$ emissions

116 have an undesirable impact on happiness. A higher air pollution index significantly reduces hedonic happiness 117 and raises depressive symptoms in Chinese citizens (Zhang et al., 2017; Gu et al., 2020). Song et al. (2020) pointed 118 out the importance of subjective evaluation of pollution; the result of the study reveals that the adverse impact of 119 bad air quality on happiness is more on unhealthy, middle, and old age people. Thus, these people are more willing 120 to pay for protecting the environment. Giovanis and Ozdamar (2018) explored the impact of air quality on mental 121 health. For improving mental health, pensioners in the European countries have a marginal willingness to pay are $122 € 221$ and $€ 88$ per year for one unit decrease in sulphur dioxide and ozone level respectively.

There is a limited literature on the nexus between environmental degradation and SWB. Out of this, few studies have been carried out regarding the relationship between energy consumption and subjective wellbeing. Afia (2019) has found the positive direct and indirect impact of energy consumption on happiness in the sample of 47 countries. Okulicz-Kozaryn and Altman (2020) have concluded that energy consumption is unrelated to happiness in developed economies, while in developing economies, people are happier with less energy consumption. Mazur and Rosa (1974) have found that the industrial nations, which are already sufficient in the energy and electricity consumption, further increase in their per capita energy or electricity consumption, have no impact on happiness.

130 Smil (2003) has found that higher energy has not improved the objective and subjective self-assessment. 131 Longhurst and Hargreaves (2019) have found that emotions like worry, fear, and care determine energy use 132 consumption and its management. Churchill et al. (2020) have examined the effect of fuel poverty on subjective 133 wellbeing (SWB) in Australia and found that an increase in fuel poverty is associated with lower levels of SWB. 134 Fanning and O'Neill (2019) have investigated the relationship between carbon-intensive consumption and 135 wellbeing for 120 countries from 2005-2015. It is found that there is a negative relation between carbon footprint and happiness in non-growing carbon footprint countries while an insignificant relation in growing carbon footprint countries.

138 Renewable energy and sustainability are interconnected with the SWB. Many Scholars explored the different aspects of sustainability, renewable energy, and SWB. Zhang et al. (2017) have found that renewable natural capital has a positive relationship with subjective wellbeing because of the fear of the extinction of non-renewable natural capital. For the low-income economies, economic factors related to livelihood which are mainly based on non-renewable energy consumption determine the level of SWB. Consequently, people may not perceive renewable energy as an essential determinant of wellbeing. Sarpong et al. (2020) have found a positive relationship between renewable energy consumption and quality of life in eight South African countries from 1995-2017. The wellbeing of the people can be enhanced by reducing global consumption and over-exploitation of natural resources (Sheth et al., 2011). In these studies, the separate impact of both non-renewable energy consumption and renewable energy consumption on SWB is not considered. Up to our best knowledge, G20 countries, which is the $80 \%$ energy consumer and the largest emitter of $\mathrm{CO}_{2}$, are not studied. The existing literature is primarily based on OECD countries, European countries, and BRICS countries. 
investigate the effect of renewable and non-renewable energy consumption on SWB in G20 countries. Moreover, this study attempts to acknowledge the role of renewable energy on human wellbeing through the channel of SWB in the panel data of 19 countries by using the latest time period, i.e., 2006-2019. Exploring the connection between renewable energy consumption and subjective wellbeing can put forward a new argument for conserving nonrenewable energy and boosting renewable energy consumption through diverse energy innovations. The rest of the paper is designed in the following way. Section 2 presents the relationship between subjective wellbeing and energy consumption in G20 countries. Section 3 describes the data sources and methods. Section 4 explains the results and discussion. Lastly, Section 5 deals with the conclusion, policy implications, and limitations of the study.

\section{Relationship Between Subjective Wellbeing and Energy Consumption in G20 Countries}

This section shows the relationship among SWB, renewable energy consumption (REC), non-renewable energy consumption (NREC), $\mathrm{CO}_{2}$ emissions, and economic growth in each $\mathrm{G} 20$ country by using scatter plot diagrams. To plot these scatter plots, data are averaged from 2006-2019.

The relationship between REC and SWB is presented in Figure 2. The scatter plot depicts the positive relationship between SWB and REC. Canada has the highest level of REC as well as SWB among the sample G20 countries. However, Australia, UK, Mexico, Germany, France, and Saudi Arabia have a high level of happiness (near 7) despite less REC. It might be possible due to the use of energy-efficient technologies.

Insert [Figure 2]

The relationship between NREC and SWB is shown in Figure 3. It shows that among the selected G20 countries, high NREC does not bring a higher level of happiness. This result supports the energy-subjective wellbeing paradox (Okulicz-Kozaryn and Altman, 2020). Moreover, China has more NREC than the United States but unable to convert into a higher happiness level. While European countries like Australia and Canada have performed well in preserving their people's happiness despite low NREC. Even though moving to high NREC, India's SWB is the lowest in the sample G20 countries.

\section{Insert [Figure 3]}

In Figure 4, the relationship between $\mathrm{SWB}$ and $\mathrm{CO}_{2}$ emissions is presented. In this figure, different scenarios can be observed. Countries like Australia, Canada, and the US have a higher level of SWB with more $\mathrm{CO}_{2}$ emissions. In contrast to this, India has the lowest level of SWB with the lowest carbon emissions. Countries like South Korea, Japan, South Africa, China, and Russia have high carbon emissions but near to the average level of SWB. While Brazil, France, Mexico, Argentina, and Italy have lesser carbon emissions but their SWB level is above the average.

Insert [Figure 4]

Lastly, Figure 5 shows the relationship between economic growth and SWB. A linear positive relationship is found for most of the countries. India, China, and South Africa have lower SWB with lower GDP per capita. While contrast to this, Canada, Australia, and United States. However, Mexico and Brazil have attained nearly 
the same level of SWB without higher per capita GDP as compared to Germany and France. Although, Japan has a high GDP per capita, but it has just above the average SWB level.

Insert [Figure 5]

\section{Data Sources and Methods}

\subsection{Data Sources}

The paper uses the panel data of 19 G20 countries for the period 2006-2019. This time period and sample G20 countries are chosen on the basis of data availability. The selected countries are Argentina, Australia, Brazil, Canada, China, France, Germany, India, Indonesia, Italy, Japan, Mexico, Russia, Saudi Arabia, South Africa, South Korea, Turkey, United Kingdom, and United States. The dependent variable is subjective wellbeing (SWB) which is measured by self-reported life satisfaction data from World Happiness Report (Yuan et al., 2018). SWB is assessed by asking respondents to show how satisfied they are with their life, a scale from 1 (not at all satisfied) to 10 (very satisfied). Independent variables are economic growth, $\mathrm{CO}_{2}$ emissions, renewable energy consumption (REC), and non-renewable energy consumption (NREC). The variables were converted into the natural logarithm form to explain the estimated coefficients in the elasticities form. A detailed description of the variables is presented in Table 1. The trend of each variable from 2006-2019 is shown in Appendix 1.

\subsection{Methodology}

\subsubsection{Unit Root Tests}

Fisher augmented Dickey-Fuller (ADF) unit root test and cross-sectionally augmented ADF (CADF) unit root tests are used to check the stationarity of the variables. The first-generation panel unit root tests neglect crosssectional dependence (Mahalik et al., 2020). Fisher ADF and CADF unit root tests consider the cross-sectional dependence issues while testing the stationarity of the variables.

\subsubsection{Panel Corrected Standard Error (PCSE) Model}

Panel corrected standard error (PCSE) approach is applied to investigate the impact of energy consumption and environmental quality on subjective wellbeing. Cross-sectional dependence (CSD), autocorrelation, and groupwise heteroskedasticity issues are generally found in panel data. PCSE model controls the problems of CSD, autocorrelation and heteroskedasticity (Reed \& Webb, 2010). Moreover, this model is suitable when the dataset has larger cross-sectional units $(\mathrm{N})$ than time period $(\mathrm{T})$. In our study, cross sectional units (19 countries) are greater than time period (14 years). Therefore, the PCSE model is applied in this study. The PCSE method has been commonly used by various researchers recently in the literature (Kumar et al., 2021; Kongkuah et al., 2021; Dash et al., 2021; Nathaniel et al., 2020; Ikpesu et al., 2019). For robustness purpose, we applied the Newey-West standard model. 


\subsubsection{Dumitrescu-Hurlin Panel Causality Test}

To understand the causation among the variables, this study employs a Granger causality test recently developed by Dumitrescu and Hurlin (2012) to demonstrate the causality relationship. This test is flexible in nature as it can be applied in heterogeneous panels and in the cases where time period is less than or higher than cross sectional units. This test considers cross-sectional dependence in estimating causality among the variables (Mahalik et al., 2020). The test can be represented in the following equation:

$y_{i t}=\alpha_{i}+\sum_{i=1}^{k} \gamma_{i}^{(k)} y_{i, t-k}+\sum_{i=1}^{k} \beta_{i}^{(k)} x_{i, t-k}+\varepsilon_{i t}$

\subsection{Model Specification}

Energy consumption includes both renewable and non-renewable energy consumption. The conventional energy sources are non-renewable energy like oil, coal, natural gas, and nuclear energy. However renewable energy sources are solar energy, tidal energy, hydropower, geothermal energy, and bioenergy (Owusu \& Sarkodie, 2016). Non-renewable energy consumption (NREC) is the most significant contributor to higher economic growth. However, Kraft and Kraft (1978) have found energy consumption has no causal relationship with economic growth, but vice versa is correct from 1950-1970 in the USA. Similarly, Yu and Choi (1985) have found a unidirectional relationship between natural gas and liquid fuel consumption to GNP for the UK and South Korea. Moreover, NREC is the most significant contributor to $\mathrm{CO}_{2}$ emissions faced by these countries (Paramati et al., 2017; Dong et al., 2019; Ahmed et al., 2019).

However, the REC promotes green growth (Shahbaz et al., 2020; Pao \& Fu, 2013) and reduces $\mathrm{CO}_{2}$ emissions for developed countries in both the short run and long run (Qiao et al., 2019; Paramati et al., 2017). While REC has no impact on $\mathrm{CO}_{2}$ emissions in developing countries. There is bidirectional causality between REC and economic growth among the panel of 30 developed and developing countries (Ahmed et al., 2019).

Subjective wellbeing is connected with energy consumption from two channels: environmental degradation $\left(\mathrm{CO}_{2}\right.$ emissions) and economic growth. On the one hand, an eco-friendly environment i.e., lesser carbon emissions enhance SWB while, on the other hand, economic growth meets the basic needs and brings material prosperity. Therefore, the empirical model examines the impact of renewable, non-renewable energy consumption, and $\mathrm{CO}_{2}$ emissions on subjective wellbeing. The functional form of the variables is represented in the following equation:

$$
S W B_{i t}=f\left(R E C_{i t}, N R E C_{i t}, C O_{2 i t}, G D P_{i t}\right)
$$

The model's general specification is represented in Equation (3) by taking the natural logarithm of Equation (2), is given as:

$\operatorname{lnSW} B_{i t}=\alpha_{0}+\alpha_{1} \operatorname{lnREC} C_{i t}+\alpha_{2} \operatorname{lnNREC}_{i t}+\alpha_{3} \operatorname{lnCO_{2it}}+\alpha_{4} \operatorname{lnGDP_{it}}+\mu_{i t}$

Where, $S W B_{i t}$ is the subjective wellbeing of a country at a time $\mathrm{t}$; $R E C_{i t}$ is the renewable energy consumption per capita of the country; $N R E C_{i t}$ is the non-renewable energy consumption per capita of the country; $\mathrm{CO}_{2 i t}$ is the environmental quality of the country; $G D P_{i t}$ is the GDP per capita. $\mu_{i t}$ denotes the error term of the equation. The detailed methodology is presented in Figure 6. 


\section{Results and Discussion}

257

258

259

260

261

262

263

264

265

266

267

268

269

270

271

272

273

274

275

276

277

278

279

280

281

282

283

284

285

286

287

288

289

Table 2 shows that the mean value is highest for GDP (9.75), followed by REC (7.35), NREC (2.33), $\mathrm{CO}_{2}$ (1.94), and SWB (1.80), respectively. Variance of REC (1.92\%) is highest, followed by GDP (1.01\%), NREC (0.92\%), $\mathrm{CO}_{2}(0.74 \%)$, and SWB $(0.15 \%)$. Table 3 displays the correlation matrix among the variables, i.e., SWB, REC, NREC, GDP, and $\mathrm{CO}_{2}$. It is found that all the variables are positively related to subjective wellbeing except for NREC.

Insert [Table 2]

Insert [Table 3]

The empirical findings of the cross-sectional dependence (CSD) test are reported in Table 4. Since the p-value is less than 0.05 , this suggest us to reject the null hypothesis of cross-sectional dependence. It reveals the existence of cross-sectional dependence in all the variables. As a result, the evidence shows the presence of CSD for REC, NREC, $\mathrm{CO}_{2}$, and GDP.

Insert [Table 4]

Table 5 reports the first-generation Fisher ADF unit root result. The findings show that subjective wellbeing is stationary at level, but renewable energy consumption, non-renewable energy consumption, economic growth, and $\mathrm{CO}_{2}$ emissions are found stationary at first difference. Overall, the considered variables are stationary either at level or at first difference. Table 6 reports the second-generation unit root test, i.e., CADF. The results reveal that the variables, i.e., SWB, REC, NREC, GDP, and $\mathrm{CO}_{2}$ emissions, contain unit roots at their level. However, at their first order, they became stationary. We can conclude that all variables are integrated with first-order.

Insert [Table 5]

Insert [Table 6]

In order to assess the long run relationship among the variables, the variables of interest should be cointegrated. This study uses three-panel cointegration tests such as the first-generation Kao, Pedroni cointegration, and secondgeneration Westerlund (2007) variance tests to establish the long-run relationship between variables. The paper initially explores the feasible cointegration among the variables using Kao (1999) panel cointegration test. The empirical finding shows that three out of five statistics reject the null hypothesis of no long-run relationship amongst the variables (Table 7). This implies that there is a presence of a long-run relationship as per the Kao test. The paper also uses Pedroni (1999) cointegration test. In this test, three out of three statistics reject the hypothesis of absence of panel cointegration amongst the variables (Table 7). So, Pedroni test of cointegration test also suggests the presence of a long-run relationship among the variables. However, Kao and Pedroni cointegration tests have one disadvantage. Both cointegration tests do not consider the presence of CSD among the variable. To overcome this, we use a second-generation cointegration test, i.e., the Westerlund test. The results of this test are presented in Table 7. This test suggests the presence of panel cointegration amongst the variables.

Insert [Table 7] 
To investigate the impact of REC, NREC, $\mathrm{CO}_{2}$, and GDP firstly, the pooled OLS, fixed effect, and random effect model are applied for preliminary analysis. The results of these three models are presented in Table 8. It is found from these three models that non-renewable energy consumption has a negative relationship with subjective wellbeing. A correlation matrix also supports this finding. The literature suggests that fixed effect and random effect models have cross-section dependence, serial correlation, and group-wise heteroscedasticity problems. This is also supported by diagnostic tests, which are presented in Table 9 . These diagnostic tests conclude that the fixed effect model suffers from cross-sectional dependence, serial correlation, and panel group-wise heteroscedasticity (Table 4 and Table 9).

Insert [Table 8]

Insert [Table 9]

To overcome the above discussed issues, the panel corrected standard error (PCSE) regression model is used. The results of this model are presented in Table 10. The results of the model reveal that renewable energy consumption has a positive impact on SWB at a 5\% significance level. With a one percent increase in renewable energy consumption, there is a $0.01 \%$ increase in SWB. This result is consistent with the studies (Qiao et al., 2019; Sarpong et al., (2020); Paramati et al., 2017, Shahbaz et al., 2020; Pao \& Fu, 2013). The result might be possible due to (a) better utilization of REC gives happiness to the people as they feel less threatened of their actions on the environment (b) REC reduces the carbon emissions and thus cleaner environment or better air quality lessens the adverse effects on health (c) G20 countries are able to manage their GDP and therefore they did not suffer from the scarcity of goods when shifting from NREC to REC. This argument can be supported by Paramati et al. (2018) who found that the impact of renewable energy is higher on economic growth than non-renewable energy in $\mathrm{G} 20$ countries.

However, the coefficient of non-renewable energy consumption is negative and significant at a $1 \%$ significance level. It is found that with a one percent increase in non-renewable energy consumption, SWB gets reduced by $0.01 \%$. The result is consistent with the studies (Okulicz-Kozaryn and Altman, 2020; Mazur and Rosa, 1974). One of the primary reasons for having a negative coefficient of NREC is $\mathrm{CO}_{2}$ emissions which is the biggest contributor to greenhouse gases and climate change, thus affecting people's lives directly. Secondly, increased use of non-renewable energy does not assure a high level of SWB, as evident in the study of Okulicz-Kozaryn and Altman (2020).

Also, the coefficient of $\mathrm{CO}_{2}$ emissions is negative and significant at $5 \%$ significance level. It implies that one percent increase in $\mathrm{CO}_{2}$ emissions leads to a decrease in SWB by $0.12 \%$. This finding is consistent with studies (Tiwari, 2014; Zhang et al., 2017; Welsch 2006; Cuñado and Gracia, 2013; Paramati et al., 2017; Dong et al., 2019; Ahmed et al., 2019).

Lastly, the result of the study shows that per capita GDP has a negative impact on subjective wellbeing at a $1 \%$ level of significance. One percent increase in per capita GDP leads to $0.12 \%$ increase in SWB. The result implies that G20 countries have been able to utilize the fruits of economic growth to enhance subjective wellbeing. This result is consistent with the studies (Frijters et al., 2004; Hagerty \& Veenhoven, 2003) and in contradiction with (Di Tella \& MacCulloch, 2008). It can be said that material prosperity have its importance in SWB in G20 
countries. It fulfils the basic needs and provide luxurious life; helps to attain the development goals in different

328 G20 countries. Summary of the findings are presented in Figure 7.

329

330

331

332

333

334

335

336

337

338

339

340

341

342

343

344

345

346

347

348

349

350

351

352

353

354

355

356

357

358

359
Insert [Table 10]

Insert [Figure 7]

\subsection{Robustness Check}

To ensure the robustness of the estimated coefficient in the PCSE model, the Newey-West standard model is adopted in this paper. The outcomes of this model are presented in Table 11, shows similar estimates to the PCSE model. Thus, it confirms that the estimated coefficients in the PCSE model are robust. Table 11 shows that a $1 \%$ increase in renewable energy consumption increases SWB by $0.004 \%$. Moreover, a $1 \%$ increase in GDP per capita raises SWB by 0.12 . A one percent rise in $\mathrm{CO}_{2}$ emissions reduces the $\mathrm{SWB}$ by $0.02 \%$ at a $5 \%$ significance level.

Insert [Table 11]

\subsection{Dumitrescu-Hurlin Panel Granger Causality Test Findings}

The paper also examines the panel granger causality test among the variables using the Dumitrescu-Hurlin (2012) test. The result of this test is presented in Table 12. There is a bidirectional causality between $\mathrm{CO}_{2}$ and economic growth, between REC and GDP, NREC and $\mathrm{CO}_{2}$, between REC and $\mathrm{CO}_{2}$, and REC and NREC. Pao et al. (2011) also found bidirectional causality between economic growth and $\mathrm{CO}_{2}$. Moreover, finding of bidirectional causality between renewable energy is consistent with Al-mulali et al. (2013), Sebri and Ben-Salha (2014), Saidi and Mbarek (2016), and Ummalla and Samal (2019). We established a one-way causal relationship running from SWB to $\mathrm{CO}_{2}$, from SWB to non-renewable energy consumption, and from non-renewable energy consumption to economic growth.

Insert [Table 12]

\section{Conclusion and Policy Implications}

The world is dealing with the crisis of food, energy, and climate change. It is urgently needed to reduce fossil fuel consumption, increase renewable energy production, and use the innovative path of improving energy efficiency for creating a low carbon global society. It is only possible when the G20 countries will reduce their emissions and come forward to help underdeveloped nations whose major population have not yet accessed electricity and clean fuels. The study empirically investigated the impact of renewable energy consumption, non-renewable energy consumption, economic growth, and $\mathrm{CO}_{2}$ emissions on subjective wellbeing in $\mathrm{G} 20$ countries during 20062019. Our empirical results confirm that both economic growth and renewable energy consumption positively influence subjective wellbeing in the selected G20 countries. Over the period, they realized the importance of renewable energy production-consumption and chosen renewable-led economic growth path. These countries have also invested in renewable sources of production techniques and awareness programs, which have enriched their subjective wellbeing. 

the subjective wellbeing in G20 countries. Based on these findings, we can propose several suggestions to reduce $\mathrm{CO}_{2}$ emissions and non-renewable energy consumption. These countries can reduce their non-renewable energy consumption by increasing investment in more renewables energy production, cleaner technologies, and strengthening environmental protection policies. G20 summit on climate change should be taken earnestly not only for adopting a green development path and sustainable energy consumption but also for enhancing citizens' happiness, which is the ultimate goal of any nation. Further, to discourage non-renewable energy consumption, these countries can reduce the fossil fuel subsidies. The study confirms a positive relationship between economic growth and subjective wellbeing. Thus, it can be advocated to promote economic growth in these countries because it can help in two ways. Firstly, shifting from non-renewable energy consumption to renewable energy consumption in each sector of the economy will result in higher production cost, which can be fulfilled by high growth. Secondly, research and development (R\&D) for innovation in energy-saving technology demands bulk investment for a longer duration which can be compensated by sustained growth.

The future scope of the paper is to explore the impact of renewable and non-renewable energy consumption in different income group countries which can provide more insights. Moreover, the effect of different forms of renewable and non-renewable energy consumption can be used to have a better understanding of the energysubjective wellbeing relationship. Studies based on primary data can also be used to understand this relationship at the household level.

\section{Declaration:}

Ethics approval and consent to participate: Not applicable

Consent for publication: Not applicable

Availability of data and materials: Data will be made available upon request

Competing interests: We do not have any conflict of interest

Funding: There is no funding to report

Authors' contributions: Neha Kumari has done literature review part while Neha Kumari and Pushp Kumar have made the analysis. While Naresh Chandra Sahu and Neha Kumari have compiled the introduction and literature review. Pushp Kumar has done the overall formatting of the paper. All authors have read and approved the manuscript.

Acknowledgements: Not Applicable

\section{References}

Afia, N. Ben. (2019). The relationship between energy consumption, economic growth and happiness. Journal of Economic Development, 44(3), 41-57.

Ahmed, M. M., \& Shimada, K. (2019). The effect of renewable energy consumption on sustainable economic development: evidence from emerging and developing economies. Energies, 12(15), 2954. 
Pedroni, M. M., \& Shimada, K. (2019). The effect of renewable energy consumption on sustainable economic development: evidence from emerging and developing economies. Energies, 12(15), 2954.

Alam, M. S., Bala, B. K., Huq, A. M. Z., \& Matin, M. A. (1991). A model for the quality of life as a function of electrical energy consumption. Energy, 16(4), 739-745. https://doi.org/10.1016/0360-5442(91)90023-F.

Al-mulali Usama, Fereidouni, H. G., Lee, J. Y., \& Sab, C. N. B. C. (2013). Examining the bi-directional long run relationship between renewable energy consumption and GDP growth. Renewable and Sustainable Energy Reviews, 22, 209-222. doi:10.1016/j.rser.2013.02.005

Case, A., \& Deaton, A. (2015). Suicide, age, and wellbeing: An empirical investigation. In Insights in the Economics of Aging (pp. 307-334). University of Chicago Press.

Churchill, A., Smyth, R., Farrell, L. (2020). Fuel poverty and subjective wellbeing. Energy Economics, 86(104650). https://doi.org/https://doi.org/10.1016/j.eneco.2019.104650

Cuñado, J., \& de Gracia, F. P. (2013). Environment and Happiness: New Evidence for Spain. Social Indicators Research, 112(3), 549-567. https://doi.org/10.1007/s11205-012-0038-4

Dash, D. P., Sethi, N., \& Dash, A. K. (2021). Education, human error, and road crash risk: An empirical investigation in the Indian states. . Journal of Public Affairs, 21(1). https://doi.org/10.1002/pa.2163

Diener, E. (2000). Subjective well-being: The science of happiness and a proposal for a national index. American psychologist, 55(1), 34.

Di Tella, R., \& MacCulloch, R. (2008). Happiness Adaptation to Income Beyond “Basic Needs” (No. w14539). National Bureau of Economic Research.

Dong, K., Jiang, H., Sun, R., Dong, X. (2019). Driving forces andmitigation potential of global CO2 emissions from 1980 through 2030: evidence from countries with different income levels. Science of the Total Environment, 649, 335-343. https://doi.org/https://doi.org/10.1016/j.scitotenv.2018.08.326.

Dumitrescu, E. I., \& Hurlin, C. (2012). Testing for Granger non-causality in heterogeneous panels. Economic modelling, 29(4), 1450-1460. https://doi.org/10.1016/j.econmod.2012.02.014

Fanning, A. L., \& O’Neill, D. W. (2019). The Wellbeing-Consumption paradox: Happiness, health, income, and carbon emissions in growing versus non-growing economies. Journal of Cleaner Production, 212, 810821.

Ferrer-i-Carbonell, A., \& Gowdy, J. M. (2007). Environmental degradation and happiness. Ecological Economics, 60(3), 509-516. https://doi.org/https://doi.org/10.1016/j.jclepro.2018.11.223

Frijters, P., Haisken-DeNew, J. P., \& Shields, M. A. (2004). Money does matter! Evidence from increasing real income and life satisfaction in East Germany following reunification. American Economic Review, 94(3), 730-740. https://doi.org/doi/pdfplus/10.1257/0002828041464551

Giovanis, E., \& Ozdamar, O. (2018). Health status, mental health and air quality: evidence from pensioners in Europe. Environmental Science and Pollution Research, 25(14), 14206-14225. https://doi.org/10.1007/s11356-018-1534-0

Goldthau, A. (2017). The G20 must govern the shift to low-carbon energy. Nature News. 546 (7657), 203. 
Gu, H., Yan, W., Elahi, E., \& Cao, Y. (2020). Air pollution risks human mental health: an implication of twostages least squares estimation of interaction effects. Environmental Science and Pollution Research, 27(2), 2036-2043. https://doi.org/10.1007/s11356-019-06612-X

Hagerty, M. R., \& Veenhoven, R. (2003). Wealth and Happiness Revisited - Growing National Income Does Go with Greater Happiness. Social Indicators Research, 64(1), 1-27. https://doi.org/https://doi.org/10.1023/A:1024790530822

Hao, H., Geng, Y., Li, W., \& Guo, B. (2015). Energy consumption and GHG emissions from China's freight transport sector: scenarios through 2050. Energy Policy, 85, 94-101. https://doi.org/https://doi.org/10.1016/j.enpol.2015.05.016

IEA. (2020). World Energy Outlook 2020. Retrieved from https://www.iea.org/reports/world-energy-outlook2020

Ikpesu, F., Vincent, O., \& Dakare, O. (2019). Growth effect of trade and investment in Sub-Saharan Africa countries: Empirical insight from panel corrected standard error (PCSE) technique. Cogent Economics \& Finance, 7(1), 1607127. https://doi.org/10.1080/23322039.2019.1607127

Im, K. S., Pesaran, M. H., \& Shin, Y. (2003). Testing for unit roots in heterogeneous panels. Journal of econometrics, 115(1), 53-74. https://doi.org/10.1016/S0304-4076(03)00092-7

Kalt, G., Wiedenhofer, D., Görg, C., \& Haberl, H. (2019). Conceptualizing energy services: A review of energy and wellbeing along the Energy Service Cascade. Energy Research \& Social Science, 53, 47-58. https://doi.org/https://doi.org/10.1016/j.erss.2019.02.026

Kao, C. (1999). Spurious regression and residual-based tests for cointegration in panel data. Journal of econometrics, 90(1), 1-44. https://doi.org/10.1016/S0304-4076(98)00023-2

Kazar, G., \& Kazar, A. (2014). The renewable energy production-economic development nexus. International Journal of Energy Economics and Policy, 4(2), 312.

Khan et al. (2014). Global estimates of energy consumption and greenhouse gas emissions. Renewable and Sustainable Energy Reviews, (29), 336-344. https://doi.org/https://doi.org/10.1016/j.rser.2013.08.091

Kongkuah, M., Yao, H., Fongjong, B. B., \& Agyemang, A. O. (2021). The role of CO 2 emissions and economic growth in energy consumption: empirical evidence from Belt and Road and OECD countries. Environmental Science and Pollution Research,1-22. https://doi.org/10.1007/s11356-02011982-8

Kraft, J., \& Kraft, A. (1978). On the Relationship Between Energy and GNP. The Journal of Energy and Development, 3(2), 401-403. Retrieved from http://www.jstor.org/stable/24806805

Kumar, P., Sahu, N. C., \& Ansari, M. A. (2021). Export Potential of Climate Smart Goods in India: Evidence from the Poisson Pseudo Maximum Likelihood Estimator. The International Trade Journal, 1-21.

Levin, A., Lin, C. F., \& Chu, C. S. J. (2002). Unit root tests in panel data: asymptotic and finite-sample properties. Journal of econometrics, 108(1), 1-24. https://doi.org/10.1016/S0304-4076(01)00098-7 
Liu, B., \& Matsushima, J. (2019). Annual changes in energy quality and quality of life: A cross-national study of 29 OECD and 37 non-OECD countries. Energy Reports, 5, 1354-1364. https://doi.org/10.1016/j.egyr.2019.09.040

Liu, J, Xin Sun, Bin Lu, Yunkun Zhang, and Rui Sun (2016). The life cycle rebound effect of air-conditioner consumption in China. Applied Energy 184,1026-1032. https://doi.org/10.1016/j.apenergy.2015.11.100

Longhurst, N., \& Hargreaves, T. (2019). Emotions and fuel poverty: The lived experience of social housing tenants in the United Kingdom. Energy Research \& Social Science, 56(101207). https://doi.org/https://doi.org/10.1016/j.erss.2019.05.017

MacKay, D. (2008). Sustainable Energy - without the hot air. UIT cambridge. https://doi.org/http://www.dspace.cam.ac.uk/handle/1810/217849

Mahalik, M. K., Mallick, H., \& Padhan, H. (2021). Do educational levels influence the environmental quality? The role of renewable and non-renewable energy demand in selected BRICS countries with a new policy perspective. Renewable Energy, 164, 419-432. https://doi.org/10.1016/j.renene.2020.09.090

Mazur, A., \& Rosa, E. (1974). Energy and life-style. Science, 186(4164), 607-610. Retrieved from http://www.jstor.org/stable/1739169

Narayan, P. K., \& Smyth, R. (2009). Multivariate Granger causality between electricity consumption, exports and GDP: evidence from a panel of Middle Eastern countries. Energy Policy, 37(1), 229-236. https://doi.org/10.1016/j.enpol.2008.08.020

Nathaniel, S., Barua, S., Hussain, H., \& Adeleye, N. (2021). The determinants and interrelationship of carbon emissions and economic growth in African economies: fresh insights from static and dynamic models. Journal of Public Affairs, 21(1), e2141. https://doi.org/10.1002/pa.2141

Niu, S., Jia, Y., Wang, W., He, R., Hu, L., \& Liu, Y. (2013). Electricity consumption and human development level: A comparative analysis based on panel data for 50 countries. International Journal of Electrical Power \& Energy Systems, 53, 338-347. https://doi.org/10.1016/j.ijepes.2013.05.024

Okulicz-Kozaryn, A., Altman, M. (2020). The Happiness-Energy Paradox: Energy Use is Unrelated to Subjective Well-Being. Applied Research Quality Life, 15, 1055-1067. https://doi.org/https://doi.org/10.1007/s11482-019-09719-y

Ouedraogo, N. S. (2013). Energy consumption and human development: Evidence from a panel cointegration and error correction model. Energy, 63, 28-41. https://doi.org/10.1016/j.energy.2013.09.067.

Owusu, P. A., \& Asumadu-Sarkodie, S. (2016). A review of renewable energy sources, sustainability issues and climate change mitigation. Cogent Engineering, 3(1). https://doi.org/https://doi.org/10.1080/23311916.2016.1167990

Pedroni, P. (1999). Critical values for cointegration tests in heterogeneous panels with multiple regressors. Oxford Bulletin of Economics and statistics, 61(S1), 653-670.

Pao, H.T., \& Fu, H.C. (2013). Renewable energy, non-renewable energy and economic growth in Brazil. 
501

502

503

504

505

506

507

508

509

510

511

512

513

514

515

516

517

518

519

520

521

522

523

524

525

526

527

528

529

530

531

532

533

534

535

Paramati, S. R., Mo, D., \& G. (2017). The effects of stock market growth and renewable energy use on CO2 emissions: Evidence from G20 countrie Frijters s, Energy Economics. Energy Economics, 66, 360-371. https://doi.org/https://doi.org/10.1016/j.eneco.2017.06.025

Paramati, S. R., Apergis, N., \& Ummalla, M. (2018). Dynamics of renewable energy consumption and economic activities across the agriculture, industry, and service sectors: evidence in the perspective of sustainable development. Environmental Science and Pollution Research, 25(2), 1375-1387. https://doi.org/10.1007/s11356-017-0552-7

Qiao, H., Zheng, F., Jiang, H., \& Dong, K. (2019). The greenhouse effect of the agriculture-economic growthrenewable energy nexus: evidence from G20 countries. Science of the Total Environment, 671, 722-731. https://doi.org/https://doi.org/10.1016/j.scitotenv.2019.03.336

Reed, W., \& Rachel, W. (2010). The PCSE Estimator is Good--Just Not As Good As You Think. Journal of Time Series Econometrics, 2(1), 1-26.

Rehdanz, K., \& Maddison, D. (2005). Climate and happiness. Ecological Economics, 52(1), 111-125. https://doi.org/https://doi.org/10.1016/j.ecolecon.2004.06.015

Rogelj, J., Den Elzen, M., Höhne, N., Fransen, T., Fekete, H., Winkler, H., \& Meinshausen. (2016). Paris Agreement climate proposals need a boost to keep warming well below 2 C. Nature, 534(7609), 631-639. https://doi.org/https://doi.org/10.1038/nature18307

Saidi, K., \& Ben Mbarek, M. (2016). Nuclear energy, renewable energy, CO 2 emissions, and economic growth for nine developed countries: Evidence from panel Granger causality tests. Progress in Nuclear Energy, 88, 364-374. doi:10.1016/j.pnucene.2016.01.018

Sarkodie, S. A., \& Strezov, V. (2019). Effect of foreign direct investments, economic development and energy consumption on greenhouse gas emissions in developing countries. Science of the Total Environment, 646, 862-871. https://doi.org/https://doi.org/10.1016/j.scitotenv.2018.07.365

Sarpong, S. Y., Bein, M. A., Gyamfi, B. A., \& Sarkodie, S. A. (2020). The impact of tourism arrivals, tourism receipts and renewable energy consumption on quality of life: A panel study of Southern African region. Heliyon, 6(11), e05351. https://doi.org/https://doi.org/10.1016/j.heliyon.2020.e05351

Sebri, M., \& Ben-Salha, O. (2014). On the causal dynamics between economic growth, renewable energy consumption, CO 2 emissions and trade openness: Fresh evidence from BRICS countries. Renewable and Sustainable Energy Reviews, 39, 14-23. doi:10.1016/j.rser.2014.07.033

Shahbaz.M, Raghutla. C, Chittedi. KR, Jiao. Z, V. X. (2020). The effect of renewable energy consumption on economic growth: Evidence from the renewable energy country attractive index. Energy. https://doi.org/https://doi.org/10.1016/j.energy.2020.118162

Sheth, J. N., Sethia, N. K., \& Srinivas, S. (2011). Mindful consumption: a customer-centric approach to sustainability. Journal of the Academy of Marketing Science, 39(1), 21-39.

Shobande, O. A. (2020). The effects of energy use on infant mortality rates in Africa. Environmental and 
Smil, V. (2003). Global ecology: environmental change and social flexibility. Routledge.

Song, Y., Zhou, A., \& Zhang, M. (2020). Exploring the effect of subjective air pollution on happiness in China. Environmental Science and Pollution Research, 27(34), 43299-43311. https://doi.org/10.1007/s11356020-10255-8

Stiglitz, J. E., Sen, A., \& Fitoussi, J. P. (2009). Report by the commission on the measurement of economic performance and social progress.

Tiwari, A. (2014) Happiness and environmental degradation: What determines happiness. Economics Bulletin, 31(4), 3192-3210.

Ummalla, M., \& Samal, A. (2019). The impact of natural gas and renewable energy consumption on CO 2 emissions and economic growth in two major emerging market economies. Environmental Science and Pollution Research, 26(20), 20893-20907. https://doi.org/10.1007/s11356-019-05388-4

UNEP. (2020). Green pandemic recovery essential to close climate action gap - UN report. Press Release.

United Nations Environment Programme. (2020). Emissions Gap Report 2020. Retrieved from UNEP, UNEP DTU Partnership

Veenhoven, R., \& Ehrhardt, J. (1995). The cross-national pattern of happiness: Test of predictions implied in three theories of happiness. Social Indicators Research, 34(1), 33-68. https://doi.org/https://doi.org/10.1007/BF01078967

Wang, Z., Bui, Q., \& Zhang, B. (2020). The relationship between biomass energy consumption and human development: Empirical evidence from BRICS countries. Energy, 194, 116906. https://doi.org/10.1016/j.energy.2020.116906

Welsch, H. (2006). Environment and happiness: Valuation of air pollution using life satisfaction data. Ecological Economics, 58(4), 801-813. https://doi.org/10.1016/j.ecolecon.2005.09.006

Welsch, H., \& Biermann, P. (2019). Poverty is a public bad: Panel evidence from subjective well-being data. Review of Income and Wealth, 65(1), 187-200.

Westerlund, J. (2007). New simple tests for panel cointegration. Econometric Reviews, 24(3), 297-316. https://doi.org/10.1080/07474930500243019

Yu, E., \& Choi, J. (1985). The Causal relationship between energy and GNP: An intenational comparison. The Journal of Energy and Development, 10(2), 249-272. https://doi.org/http://www.jstor.org/stable/24807818

Yuan, L., Shin, K., \& Managi, S. (2018). Subjective wellbeing and environmental quality: the impact of air pollution and green coverage in China. Ecological economics, 153, 124-138. https://doi.org/10.1016/j.ecolecon.2018.04.033

Zhang, S., Shi, Q., \& Cheng, M. (2017). Renewable natural capital, the biocapacity, and subjective wellbeing. Journal of Cleaner Production, 150, 277-286. https://doi.org/https://doi.org/10.1016/j.jclepro.2017.03.021. 
571 Zhang, X., Zhang, X., \& Chen, X. (2017). Happiness in the air: How does a dirty sky affect mental health and 572 subjective wellbeing? Journal of Environmental Economics and Management, 85, 81-94. $573 \quad$ https://doi.org/10.1016/j.jeem.2017.04.001 
Table 1. Description of the Variables

\begin{tabular}{lll}
\hline Symbol & Description & Source \\
\hline $\ln$ SWB & $\begin{array}{l}\text { Life ladder in natural logarithm } \\
\text { Renewable energy consumption per capita }(\mathrm{kWh}) \text { in natural } \\
\text { lnRegarithm }\end{array}$ & World Happiness Report \\
$\ln$ Nonrenewable energy consumption per capita $(\mathrm{kWh})$ in & Energy Statistics \\
$\ln \mathrm{nO}_{2}$ & $\mathrm{CO}_{2}$ emissions per capita in natural logarithm & Energy Statistics \\
$\ln \mathrm{GDP}$ & GDP per capita in natural logarithm & World Development \\
\end{tabular}

Table 2. Summary Statistics of the Variables

\begin{tabular}{lccccc}
\hline Variable & Observations & Mean & Standard Deviation & Minimum & Maximum \\
\hline $\operatorname{lnSWB}$ & 266 & 1.806 & 0.154 & 1.178 & 2.044 \\
$\operatorname{lnREC}$ & 264 & 7.349 & 1.923 & -2.813 & 10.344 \\
$\ln \mathrm{NREC}$ & 266 & 2.334 & 0.923 & 0.890 & 4.793 \\
$\operatorname{lnCO}_{2}$ & 266 & 1.936 & 0.740 & 0.099 & 3.015 \\
$\operatorname{lnGDP}$ & 266 & 9.746 & 1.014 & 7.009 & 10.954 \\
\hline
\end{tabular}

Table 3. Correlation Matrix

\begin{tabular}{llllll}
\hline & $\ln S W B$ & $\ln R E C$ & $\ln R E C$ & $\operatorname{lnCO}_{2}$ & $\operatorname{lnGDP}$ \\
\hline $\ln$ SWB & 1 & & & & \\
$\ln$ REC & 0.369 & 1 & & & \\
$\ln$ NREC & -0.203 & 0.056 & 1 & & \\
$\operatorname{lnCO}_{2}$ & 0.464 & 0.051 & 0.210 & 1 & 1 \\
$\operatorname{lnGDP}$ & 0.768 & 0.393 & -0.089 & 0.739 & \\
\hline
\end{tabular}

Table 4. Cross-Sectional Dependency Test

\begin{tabular}{lcc}
\hline & CD-test & P-value \\
\hline $\ln$ SWB & 0.55 & 0.584 \\
$\operatorname{lnREC}$ & $28.2 * * *$ & 0.000 \\
$\ln \mathrm{FDP}$ & $29.04 * * *$ & 0.000 \\
$\ln \mathrm{NREC}$ & 4.77 & 0.000 \\
$\operatorname{lnCO}{ }_{2}$ & 0.12 & 0.904 \\
\hline
\end{tabular}

Note. $* * * \mathrm{p}<0.01, * * \mathrm{p}<0.05$, and $* \mathrm{p}<0.1$ 
Table 5. Fisher ADF Unit Root Test

\begin{tabular}{|c|c|c|c|c|c|c|}
\hline \multirow[b]{2}{*}{ Variables } & & \multicolumn{3}{|c|}{ At level } & \multicolumn{2}{|c|}{ At first difference } \\
\hline & & & Statistics & P-value & Statistics & P-value \\
\hline \multirow{4}{*}{$\operatorname{lnSWB}$} & Inverse Chi2 & $\mathrm{P}$ & 71.068 & 0.001 & 153.814 & 0.000 \\
\hline & Inverse normal & $\mathrm{Z}$ & -2.497 & 0.006 & -8.323 & 0.000 \\
\hline & Inverse logit & $\mathrm{L}$ & -2.515 & 0.007 & -9.437 & 0.000 \\
\hline & Modified inverse Chi2 & $\mathrm{Pm}$ & 3.793 & 0.000 & 13.285 & 0.000 \\
\hline \multirow{4}{*}{$\ln R E C$} & Inverse Chi2 & $\mathrm{P}$ & 36.985 & 0.516 & 144.746 & 0.000 \\
\hline & Inverse normal & $\mathrm{Z}$ & 2.281 & 0.989 & -7.654 & 0.000 \\
\hline & Inverse logit & $\mathrm{L}$ & 2.182 & 0.984 & -8.809 & 0.000 \\
\hline & Modified inverse Chi2 & $\mathrm{Pm}$ & -0.116 & 0.546 & 12.245 & 0.000 \\
\hline \multirow{4}{*}{$\operatorname{lnGDP}$} & Inverse Chi2 & $\mathrm{P}$ & 27.569 & 0.894 & 191.221 & 0.000 \\
\hline & Inverse normal & $\mathrm{Z}$ & 2.919 & 0.998 & -8.861 & 0.000 \\
\hline & Inverse logit & $\mathrm{L}$ & 2.822 & 0.997 & -11.674 & 0.000 \\
\hline & Modified inverse Chi2 & $\mathrm{Pm}$ & -1.197 & 0.884 & 17.576 & 0.000 \\
\hline \multirow{4}{*}{$\operatorname{lnNREC}$} & Inverse Chi2 & $\mathrm{P}$ & 71.003 & 0.001 & 109.224 & 0.000 \\
\hline & Inverse normal & $\mathrm{Z}$ & -1.291 & 0.098 & -5.212 & 0.000 \\
\hline & Inverse logit & $\mathrm{L}$ & -2.009 & 0.024 & -6.080 & 0.000 \\
\hline & Modified inverse Chi2 & $\mathrm{Pm}$ & 3.786 & 0.000 & 8.170 & 0.000 \\
\hline \multirow{4}{*}{$\operatorname{lnCO}_{2}$} & Inverse Chi2 & $\mathrm{P}$ & 31.048 & 0.781 & 133.492 & 0.000 \\
\hline & Inverse normal & $\mathrm{Z}$ & 1.014 & 0.845 & -7.274 & 0.000 \\
\hline & Inverse logit & $\mathrm{L}$ & 1.073 & 0.857 & -8.117 & 0.000 \\
\hline & Modified inverse Chi2 & $\mathrm{Pm}$ & -0.797 & 0.787 & 10.954 & 0.000 \\
\hline
\end{tabular}

Table 6. CADF Unit Root Test

\begin{tabular}{lcccc}
\hline & \multicolumn{2}{c}{ At level } & \multicolumn{2}{c}{ At first difference } \\
\hline Variables & t-bar & P-value & t-bar & P-value \\
\hline $\ln$ SWB & -2.428 & 0.242 & -3.771 & 0.000 \\
$\ln$ EEC & -1.658 & 0.049 & -7.841 & 0.000 \\
$\ln$ GDP & -2.424 & 0.247 & -3.176 & 0.000 \\
$\operatorname{lnNREC}$ & -1.649 & 0.991 & -3.273 & 0.000 \\
$\operatorname{lnCO}_{2}$ & -1.836 & 0.948 & -3.264 & 0.000 \\
\hline
\end{tabular}


Table 7. Cointegration Tests

\begin{tabular}{|c|c|c|}
\hline \multicolumn{3}{|c|}{ Kao Test for Cointegration } \\
\hline & Statistic & P-value \\
\hline Modified Dickey-Fuller t & -0.736 & 0.231 \\
\hline Dickey-Fuller t & $-1.709 * *$ & 0.044 \\
\hline Augmented Dickey-Fuller t & -0.409 & 0.341 \\
\hline Unadjusted modified Dickey & $-5.391 * * *$ & 0.000 \\
\hline Unadjusted Dickey-Fuller t & $-4.232 * * *$ & 0.000 \\
\hline \multicolumn{3}{|c|}{ Pedroni Test for Cointegration } \\
\hline Modified Phillips-Perron $\mathrm{t}$ & $3.482 * * *$ & 0.000 \\
\hline Phillips-Perron t & $-5.511 * * *$ & 0.000 \\
\hline Augmented Dickey-Fuller t & $-6.086 * * *$ & 0.000 \\
\hline \multicolumn{3}{|c|}{ Westerlund Test for Cointegration } \\
\hline Variance ratio (all panel are cointegrated) & $1.352 *$ & 0.088 \\
\hline Variance ratio (some panel are cointegrated) & $-1.344 *$ & 0.090 \\
\hline
\end{tabular}

Note. $* * * \mathrm{p}<0.01, * * \mathrm{p}<0.05$, and $* \mathrm{p}<0.1$

Table 8. Panel Regression Models

\begin{tabular}{|c|c|c|c|}
\hline Variables & OLS & Fixed Effects & Random Effects \\
\hline \multirow[t]{2}{*}{$\operatorname{lnREC}$} & 0.004 & 0.006 & 0.002 \\
\hline & $(-0.004)$ & $(-0.007)$ & $(-0.006)$ \\
\hline \multirow[t]{2}{*}{$\operatorname{lnNREC}$} & $-0.017 * *$ & $-0.158 * *$ & $-0.058 * * *$ \\
\hline & $(-0.007)$ & $(-0.079)$ & $(-0.022)$ \\
\hline \multirow[t]{2}{*}{$\operatorname{lnCO}{ }_{2}$} & $-0.029 * *$ & 0.081 & 0.011 \\
\hline & $(-0.015)$ & $(-0.065)$ & $(-0.035)$ \\
\hline \multirow[t]{2}{*}{$\operatorname{lnGDP}$} & $0.127 * * *$ & 0.031 & $0.076 * * *$ \\
\hline & $(-0.011)$ & -0.0470 & $(-0.027)$ \\
\hline \multirow[t]{2}{*}{ Constant } & $0.631 * * *$ & $1.669 * * *$ & $1.163 * * *$ \\
\hline & $(-0.084)$ & $(-0.379)$ & $(-0.215)$ \\
\hline Observations & 264 & 264 & 264 \\
\hline R-squared & 0.621 & 0.020 & \\
\hline Number of Cross-Sections & & 19 & 19 \\
\hline Hausman Test & & $\begin{array}{c}\text { Chi }^{2} \\
12.22\end{array}$ & $\begin{array}{c}\text { P-value } \\
0.0158\end{array}$ \\
\hline
\end{tabular}

Note: (a) Standard errors in parentheses (b)*** $\mathrm{p}<0.01$, ** $\mathrm{p}<0.05$, and $* \mathrm{p}<0.1$ 
Table 9. Diagnostic Tests

\begin{tabular}{lll}
\hline & Chi-square & P-value \\
\hline Heteroscedasticity & $13245.76^{* * *}$ & 0.000 \\
Serial-Correlation & $7.372 * *$ & 0.014 \\
\hline
\end{tabular}

Note: $* * * \mathrm{p}<0.01, * * \mathrm{p}<0.05$, and $* \mathrm{p}<0.1$

Table 10. Results of Panel Corrected Standard Errors (PCSE)

\begin{tabular}{lccc}
\hline Variables & Coefficients & Panel Corrected Standard Error & P-value \\
\hline lnREC & $0.004^{* *}$ & 0.002 & 0.045 \\
$\ln N R E C$ & $-0.017 * * *$ & 0.004 & 0.000 \\
$\operatorname{lnCO} 2$ & $-0.029 * * *$ & 0.009 & 0.002 \\
$\operatorname{lnGDP}$ & $0.127^{* * *}$ & 0.008 & 0.000 \\
Constant & 0.631 & 0.063 & 0.000 \\
R-squared & 0.6213 & & \\
Number of observations & 266 & & \\
Number of Groups & 19 & & \\
\hline
\end{tabular}

Note: $* * * \mathrm{p}<0.01, * * \mathrm{p}<0.05$, and $* \mathrm{p}<0.1$

Table 11. Results of Newey-West Standard Error Model

\begin{tabular}{|c|c|c|c|}
\hline Variables & Coefficients & Newey-West Standard Error & P-value \\
\hline $\operatorname{lnREC}$ & 0.004 & 0.004 & 0.283 \\
\hline $\operatorname{lnNREC}$ & $-0.017 * *$ & 0.007 & 0.022 \\
\hline $\operatorname{lnCO} 2$ & $-0.029 * *$ & 0.014 & 0.041 \\
\hline $\operatorname{lnGDP}$ & $0.127 * * *$ & 0.011 & 0.000 \\
\hline Constant & $0.631 * * *$ & 0.089 & 0.000 \\
\hline Number of observations & 266 & & \\
\hline Number of Groups & 19 & & \\
\hline
\end{tabular}

Note: $* * * \mathrm{p}<0.01, * * \mathrm{p}<0.05$, and $* \mathrm{p}<0.1$ 
Table 12. Dumitrescu-Hurlin Panel Granger Causality Tests

\begin{tabular}{|c|c|c|c|c|}
\hline Null Hypothesis: & W-Stat. & Zbar-Stat. & Prob. & Conclusion \\
\hline lnGDP does not homogeneously cause lnSWB & 1.900 & 1.309 & 0.191 & \\
\hline lnSWB does not homogeneously cause lnGDP & 1.975 & 1.459 & 0.145 & \\
\hline $\operatorname{lnCO}_{2}$ does not homogeneously cause $\operatorname{lnSWB}$ & 1.630 & 0.764 & 0.445 & \\
\hline $\operatorname{lnSWB}$ does not homogeneously cause $\operatorname{lnCO}_{2}$ & 2.982 & $3.487 * * *$ & 0.001 & $\operatorname{lnSWB} \rightarrow \operatorname{lnCO} \mathrm{O}_{2}$ \\
\hline lnNREC does not homogeneously cause $\operatorname{lnSWB}$ & 2.028 & 1.566 & 0.118 & \\
\hline lnSWB does not homogeneously cause lnNREC & 2.828 & $3.178 * * *$ & 0.002 & $\operatorname{lnSWB} \rightarrow \operatorname{lnNREC}$ \\
\hline lnREC does not homogeneously cause lnSWB & 1.412 & 0.314 & 0.754 & \\
\hline lnSWB does not homogeneously cause $\operatorname{lnREC}$ & 1.654 & 0.798 & 0.425 & \\
\hline $\operatorname{lnCO}{ }_{2}$ does not homogeneously cause lnGDP & 2.680 & $2.879 * * *$ & 0.004 & $\operatorname{lnCO} \mathrm{O}_{2} \leftrightarrow \operatorname{lnGDP}$ \\
\hline $\operatorname{lnGDP}$ does not homogeneously cause $\operatorname{lnC\mathrm {C}_{2}}$ & 3.002 & $3.528 * * *$ & 0.000 & \\
\hline lnNREC does not homogeneously cause lnGDP & 2.117 & $1.745^{*}$ & 0.081 & $\operatorname{lnNREC} \rightarrow \operatorname{lnGDP}$ \\
\hline lnGDP does not homogeneously cause lnNREC & 1.358 & 0.218 & 0.828 & \\
\hline lnREC does not homogeneously cause lnGDP & 2.374 & $2.235^{* *}$ & 0.025 & $\ln R E C \leftrightarrow \operatorname{lnGDP}$ \\
\hline lnGDP does not homogeneously cause lnREC & 2.899 & $3.284 * * *$ & 0.001 & \\
\hline lnNREC does not homogeneously cause $\operatorname{lnCO}_{2}$ & 2.654 & $2.828 * * *$ & 0.005 & $\operatorname{lnNREC} \leftrightarrow \operatorname{lnCO}_{2}$ \\
\hline $\operatorname{lnCO}{ }_{2}$ does not homogeneously cause $\operatorname{lnNREC}$ & 2.881 & $3.283 * * *$ & 0.001 & \\
\hline lnREC does not homogeneously cause $\operatorname{lnCO}_{2}$ & 3.497 & $4.478 * * *$ & 0.000 & $\operatorname{lnREC} \leftrightarrow \ln \mathrm{CO}_{2}$ \\
\hline $\operatorname{lnCO}{ }_{2}$ does not homogeneously cause lnREC & 3.155 & $3.794 * * *$ & 0.000 & \\
\hline
\end{tabular}


lnREC does not homogeneously cause lnNREC

InNREC does not homogeneously cause lnREC

3.296

2.258

$4.075^{* * *}$

$2.003 * *$

0.000

0.045

Note: $* * * \mathrm{p}<0.01, * * \mathrm{p}<0.05$, and $* \mathrm{p}<0.1 . \rightarrow$ denotes unidirectional causality and $\leftrightarrow$ shows bidirectional causality
$\operatorname{lnREC} \leftrightarrow \operatorname{lnNREC}$ 


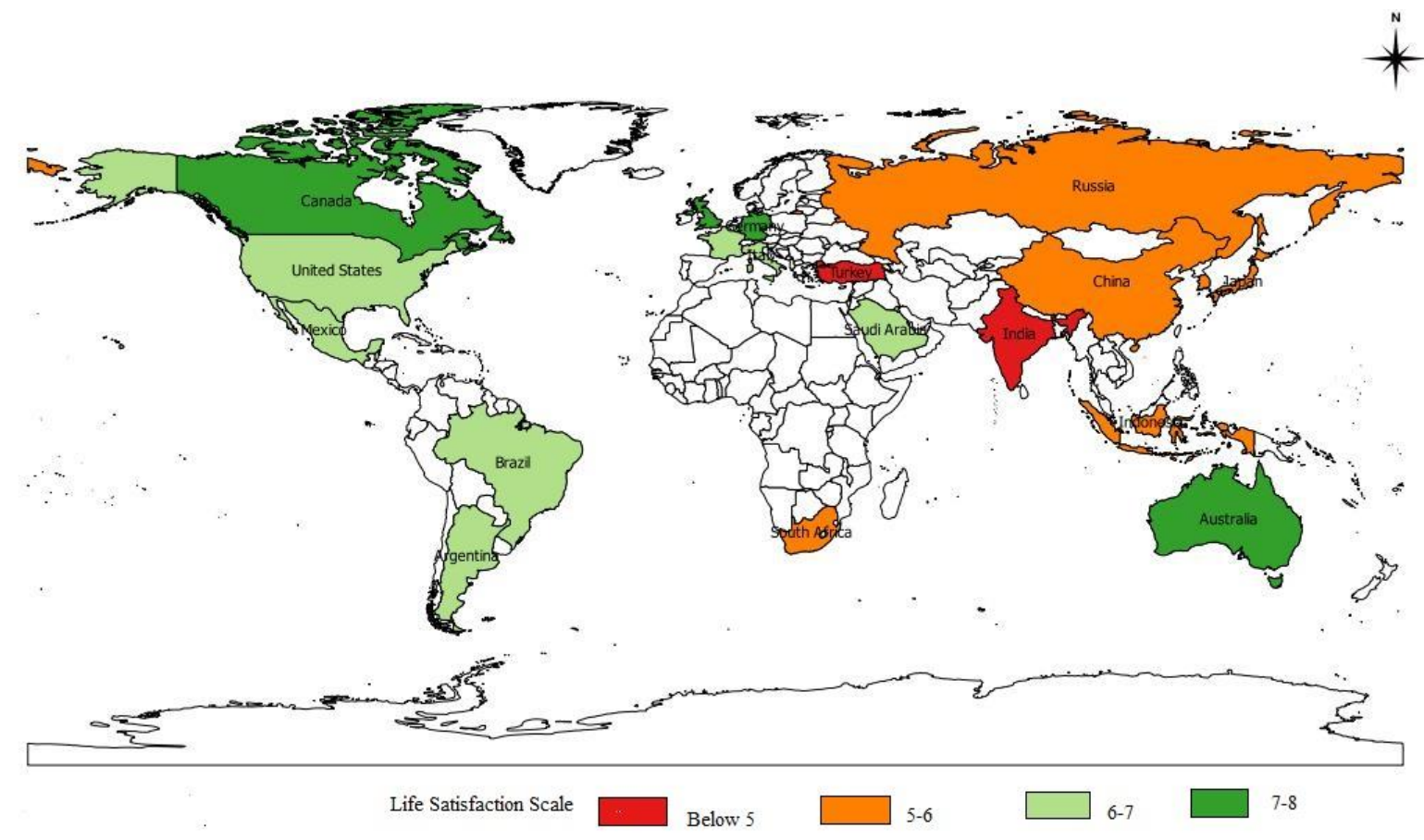

Figure 1. G20 Countries in World Happiness Report 2019

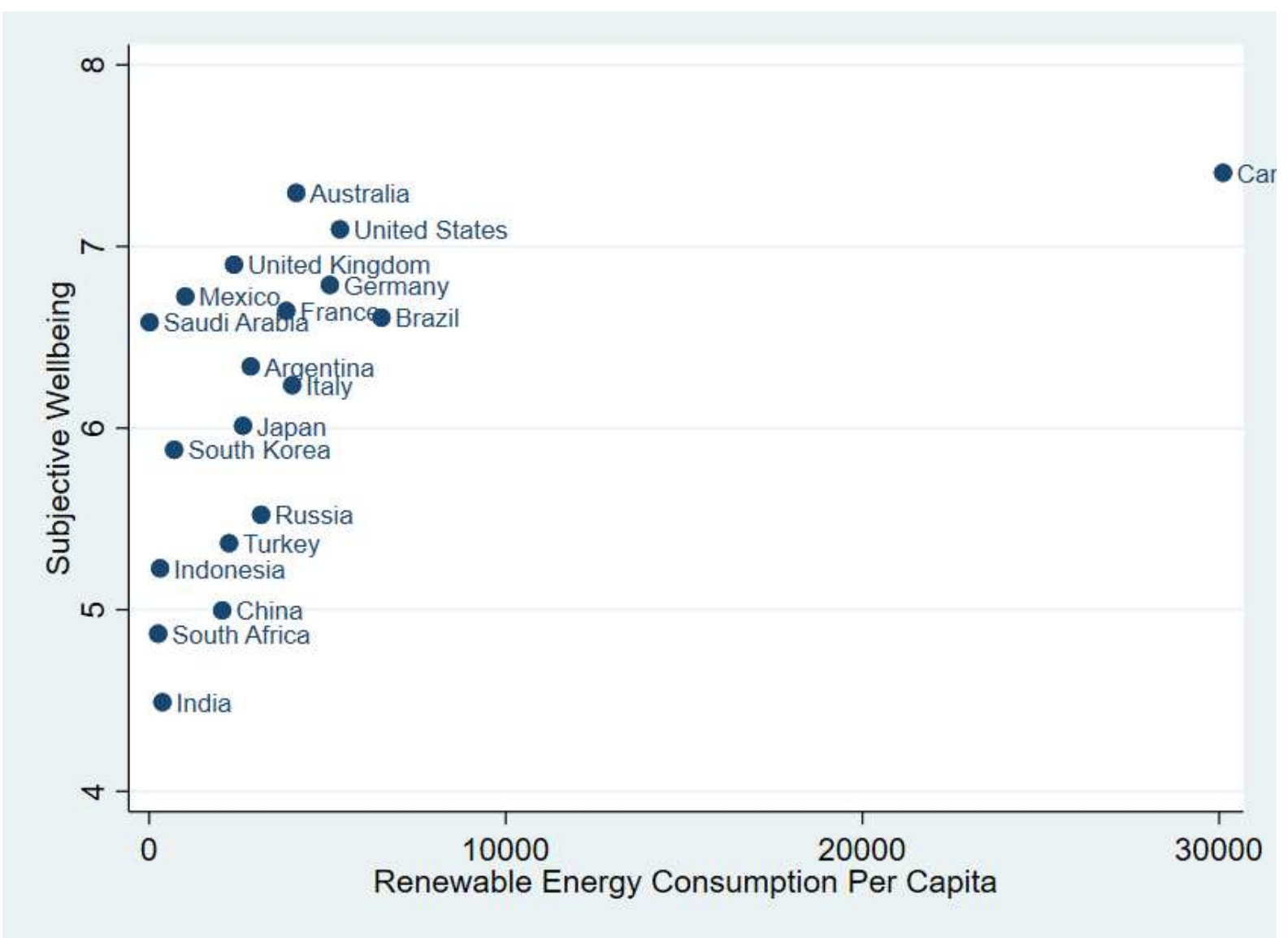

Figure 2. Subjective Wellbeing and REC 


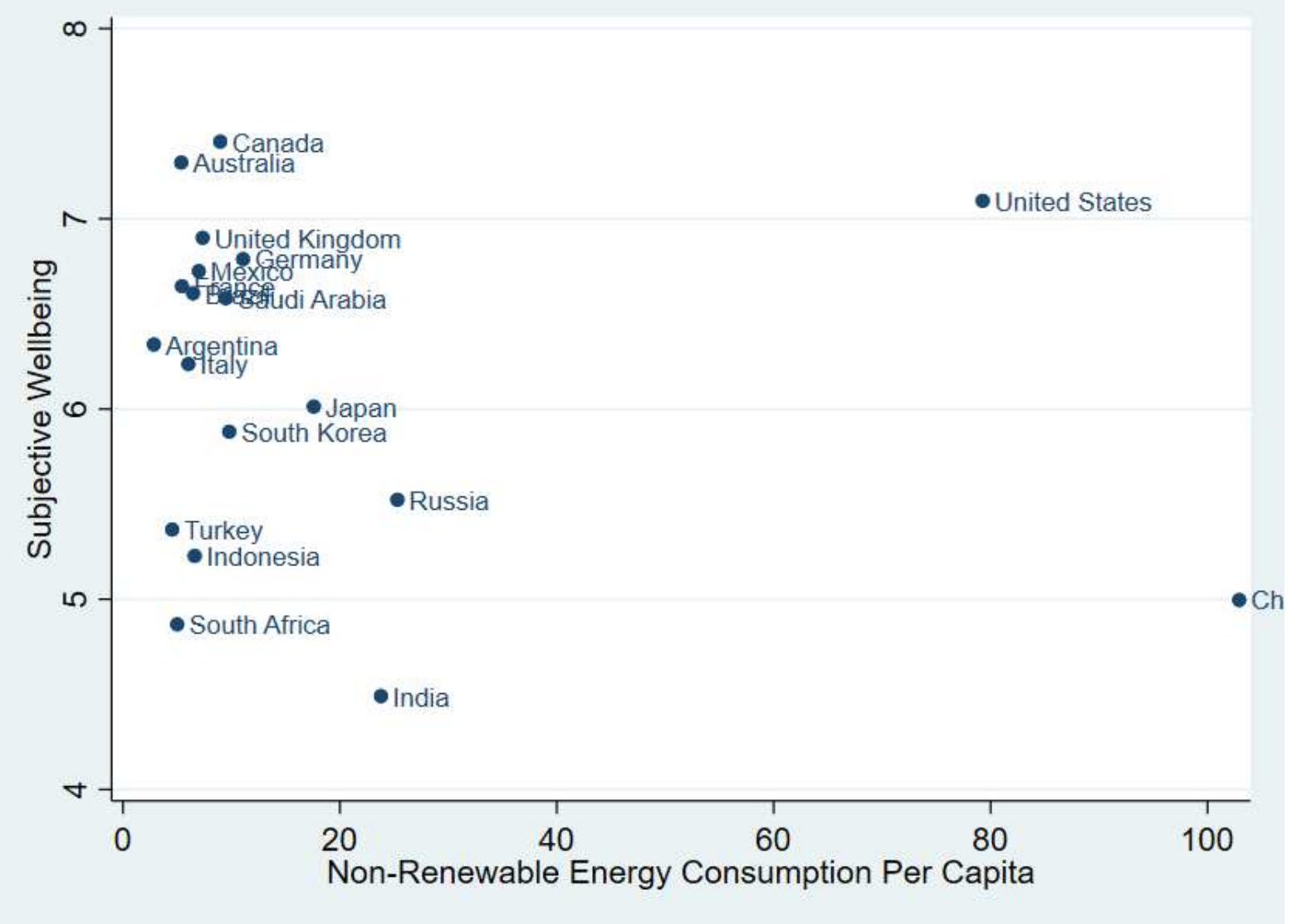

Figure 3. Subjective Wellbeing and NREC 


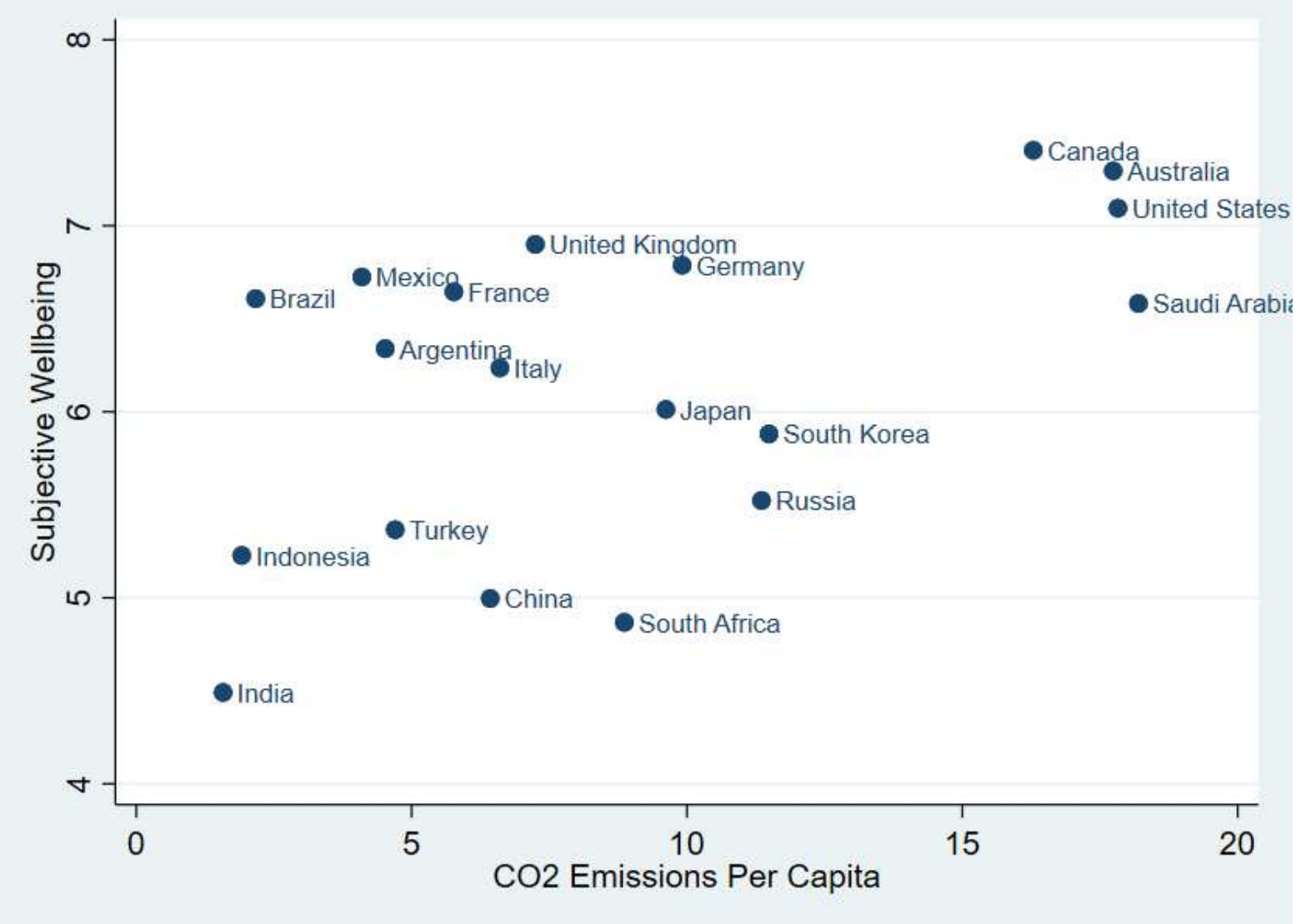

Figure 4. Subjective Wellbeing and $\mathrm{CO}_{2}$ Emissions 


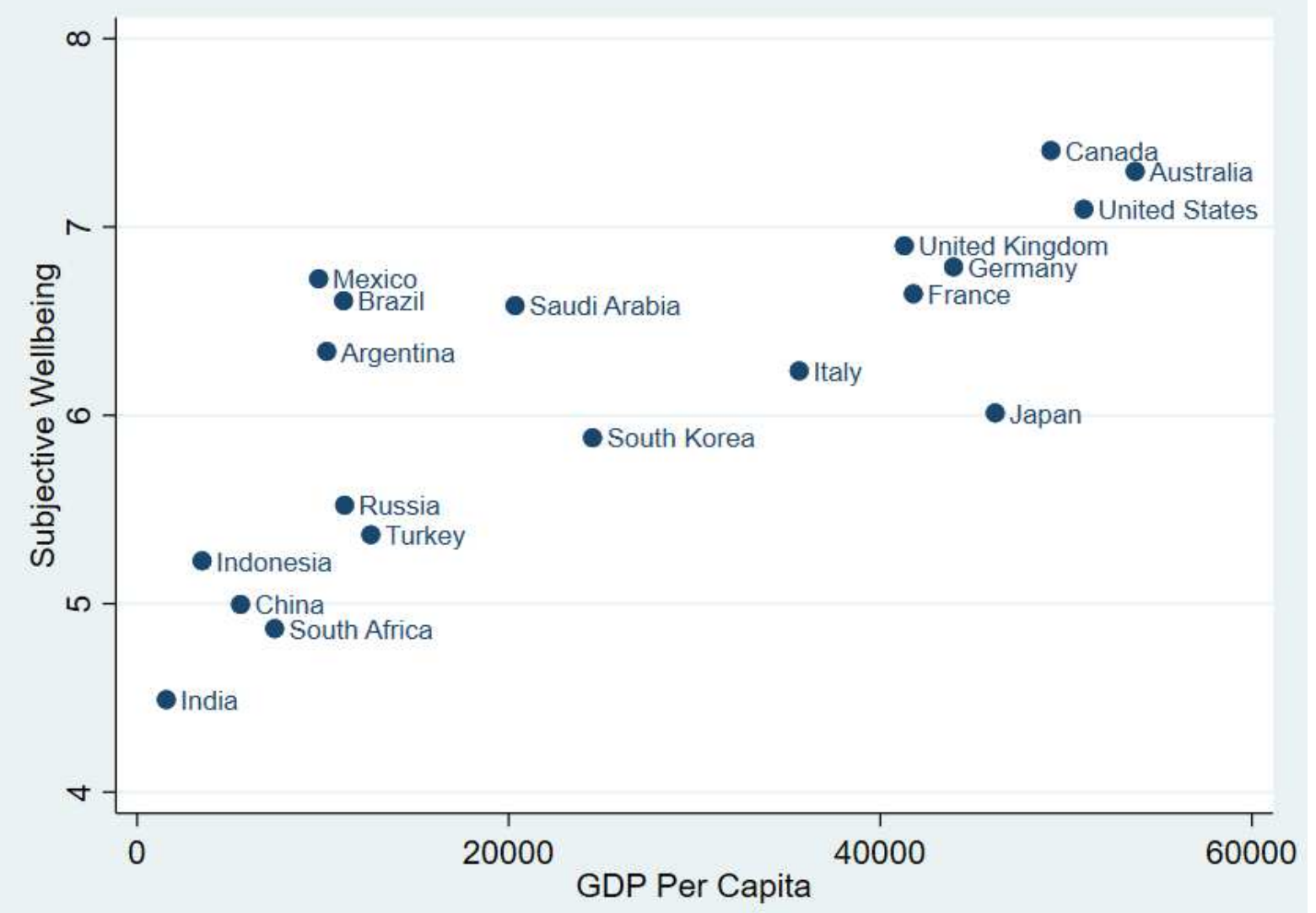

Figure 5. Subjective Wellbeing and GDP Per Capita 


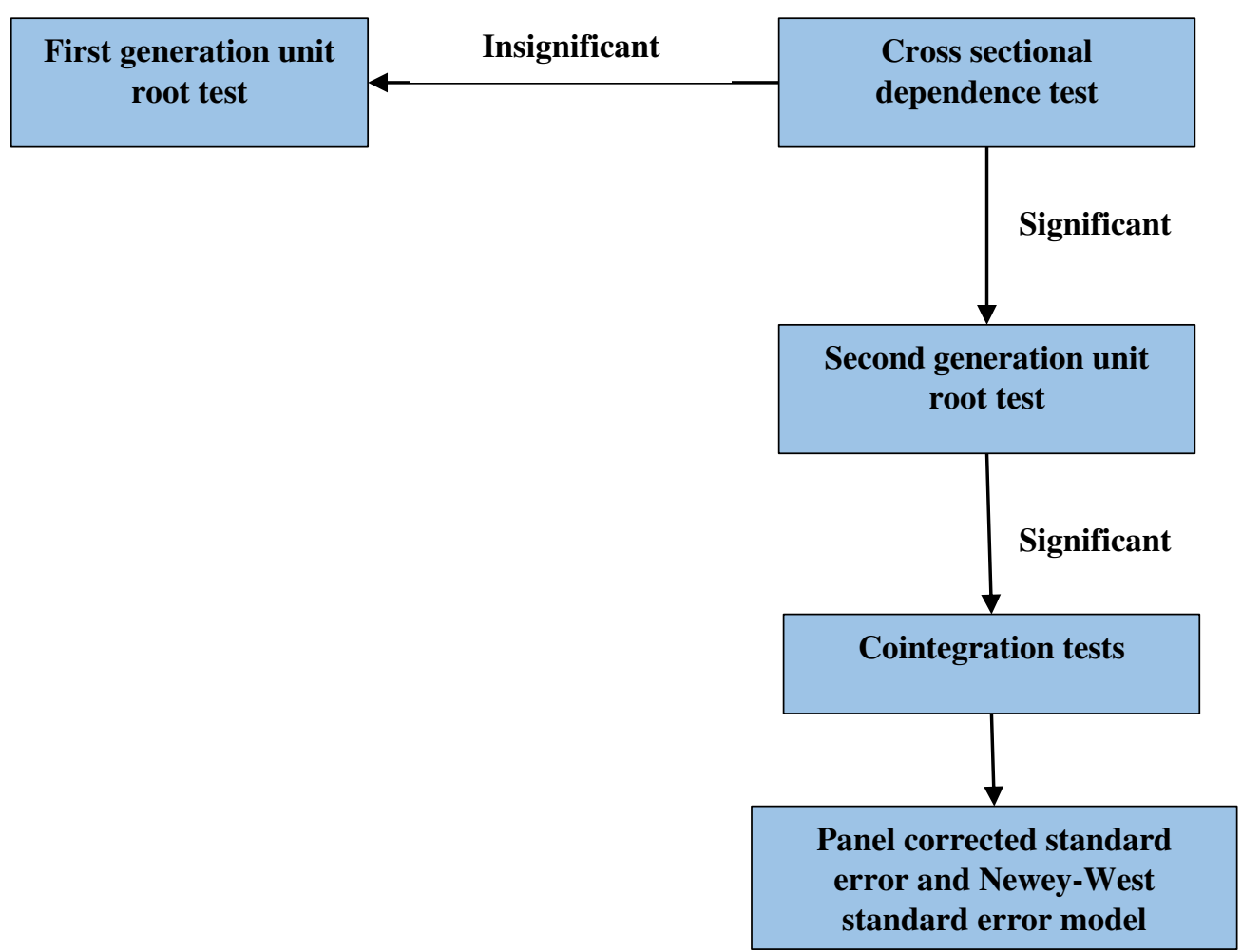

Figure 6. Scheme of Methodology 


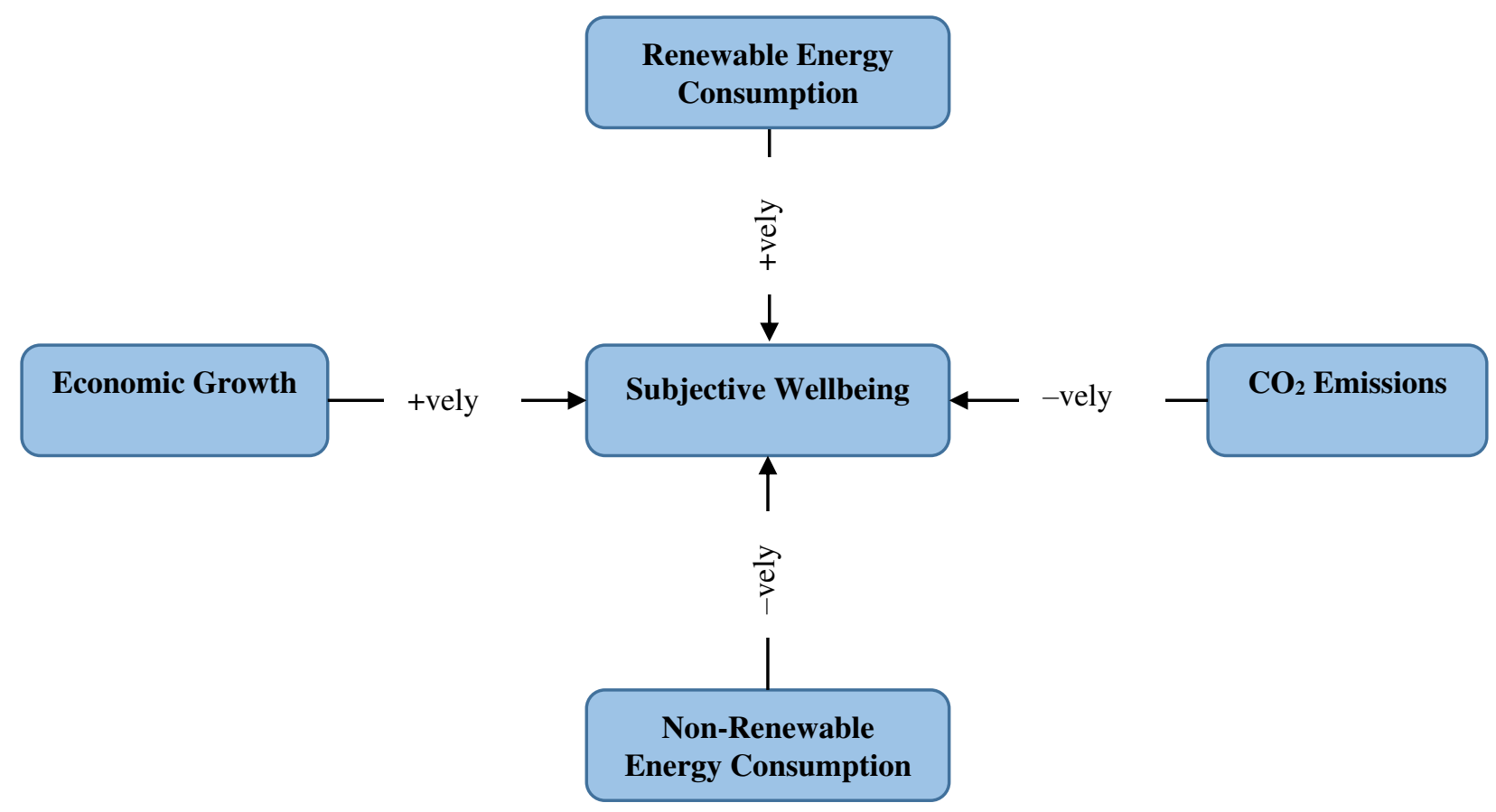

Figure 7. Summary of Findings 
Appendix 1: Trends of the Variables for G20 Countries during 2006-19
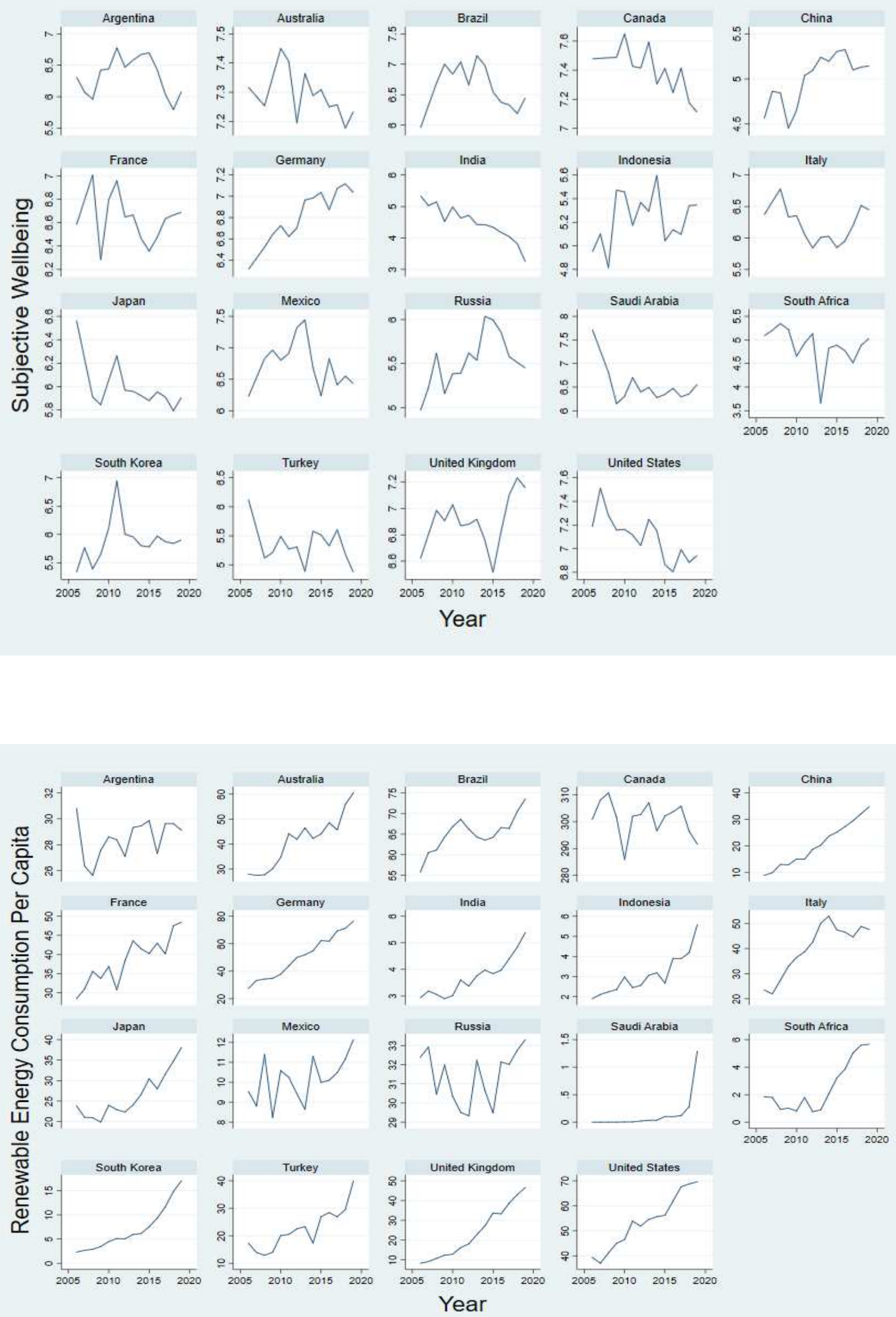

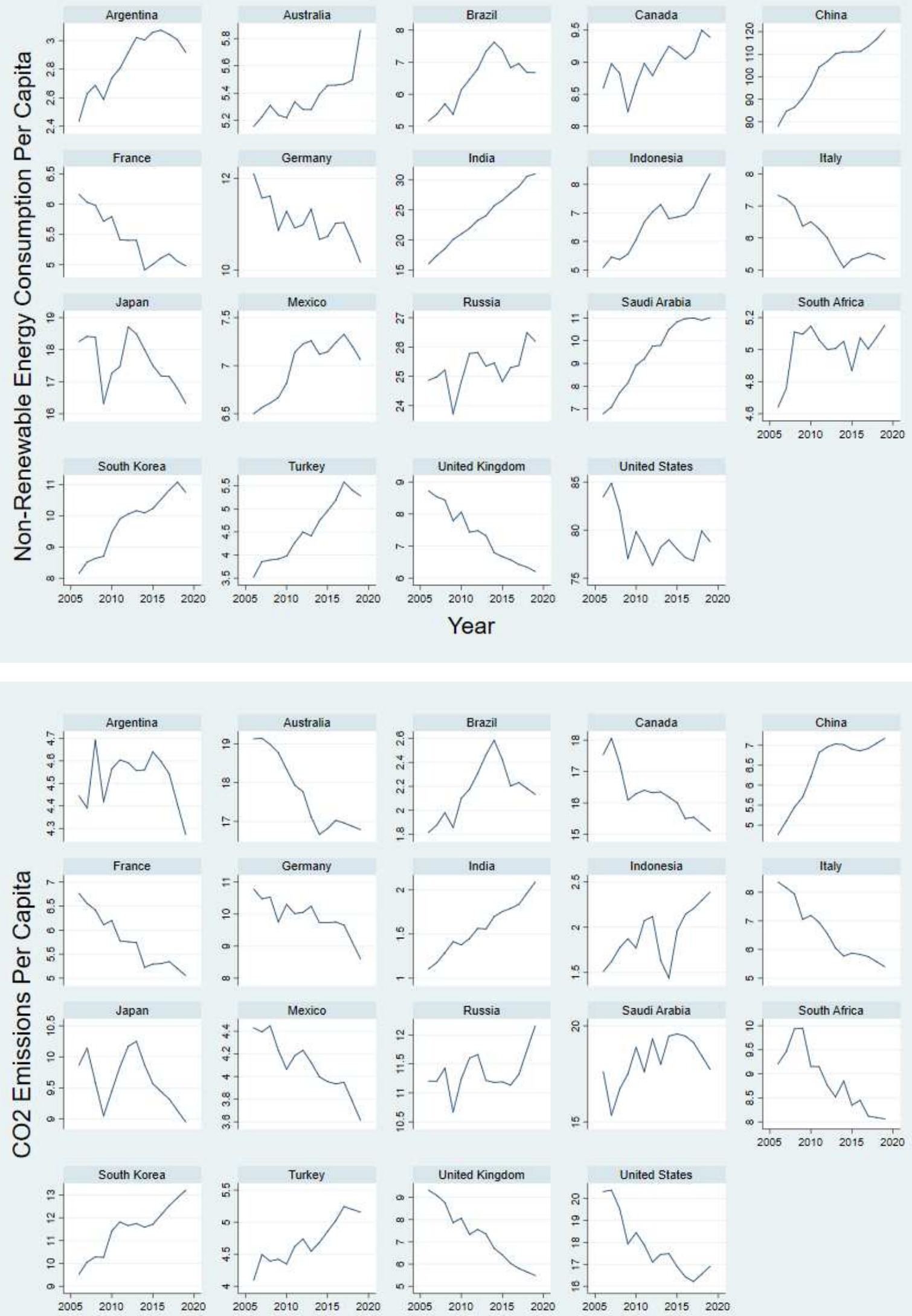

Year 

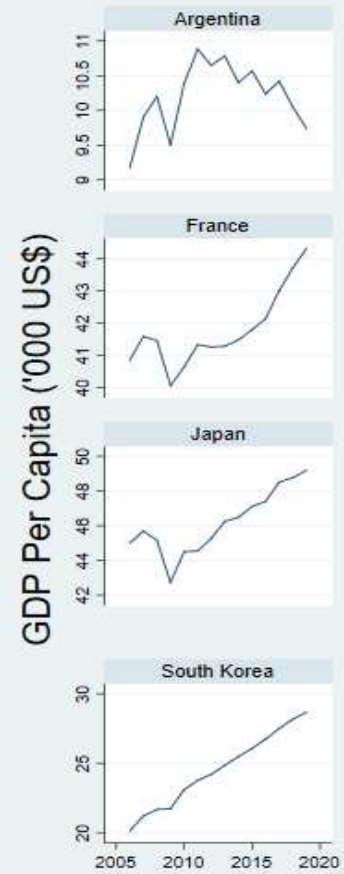
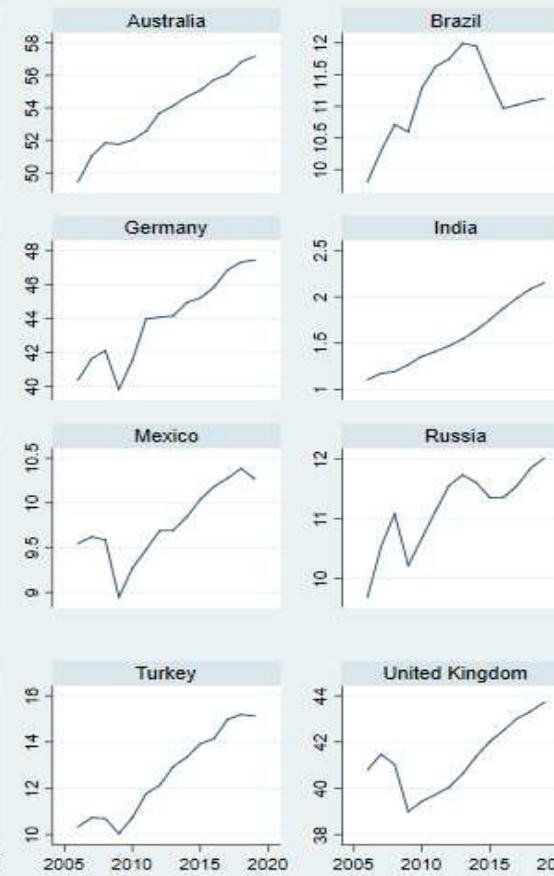

India

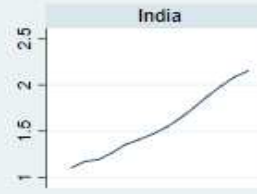

Mexico
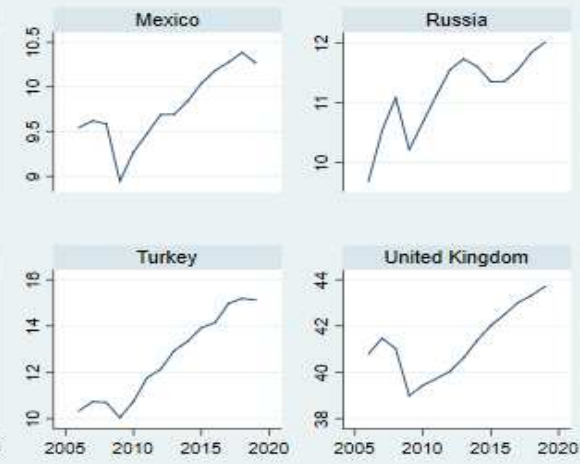

Year
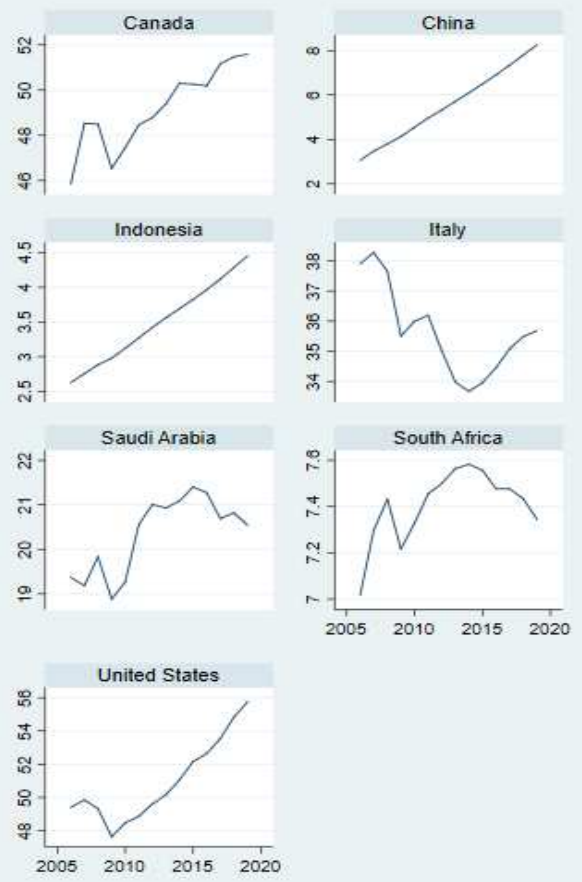


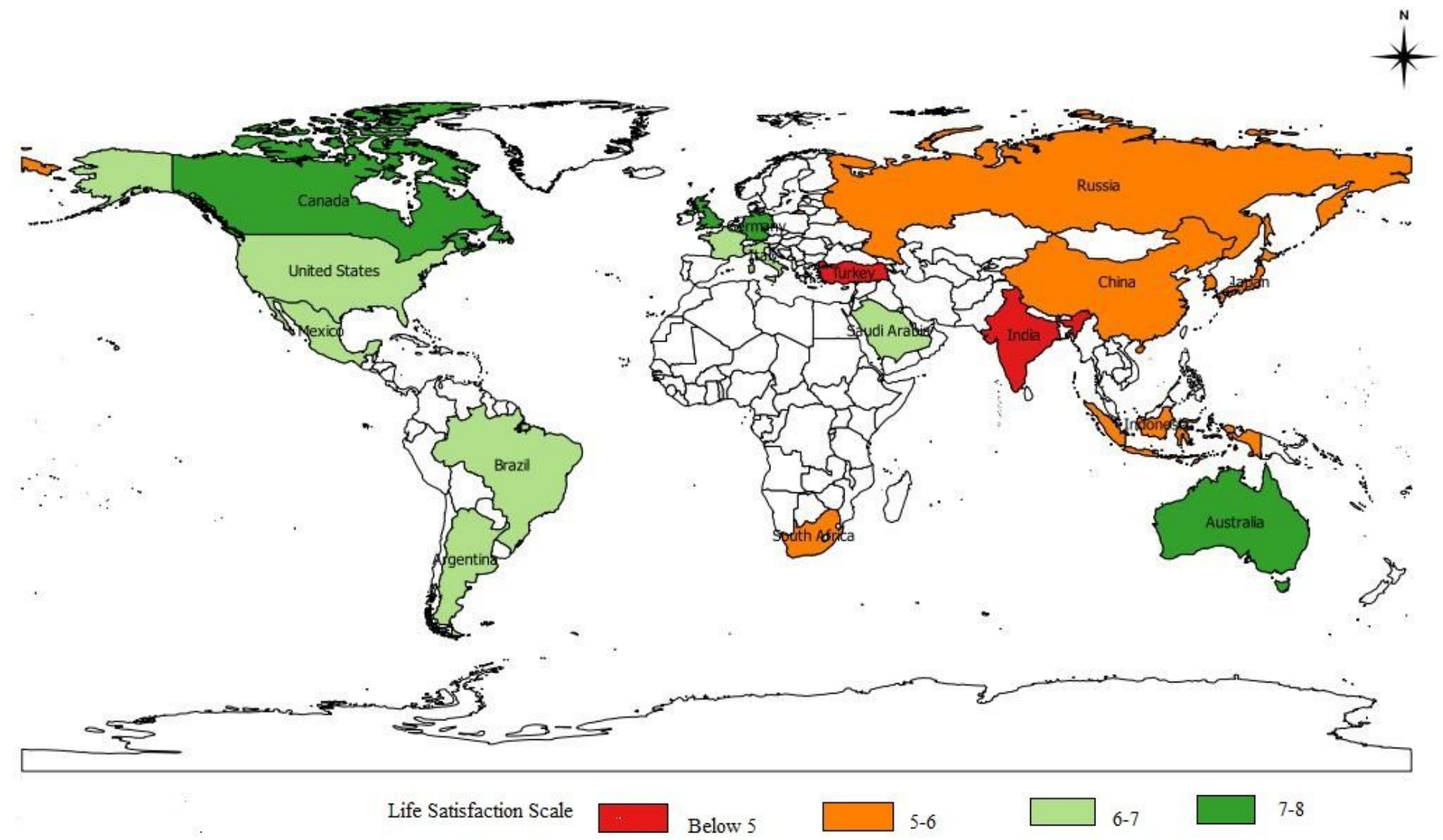

Figure 1

G20 Countries in World Happiness Report 2019. Note: The designations employed and the presentation of the material on this map do not imply the expression of any opinion whatsoever on the part of Research Square concerning the legal status of any country, territory, city or area or of its authorities, or concerning the delimitation of its frontiers or boundaries. This map has been provided by the authors. 


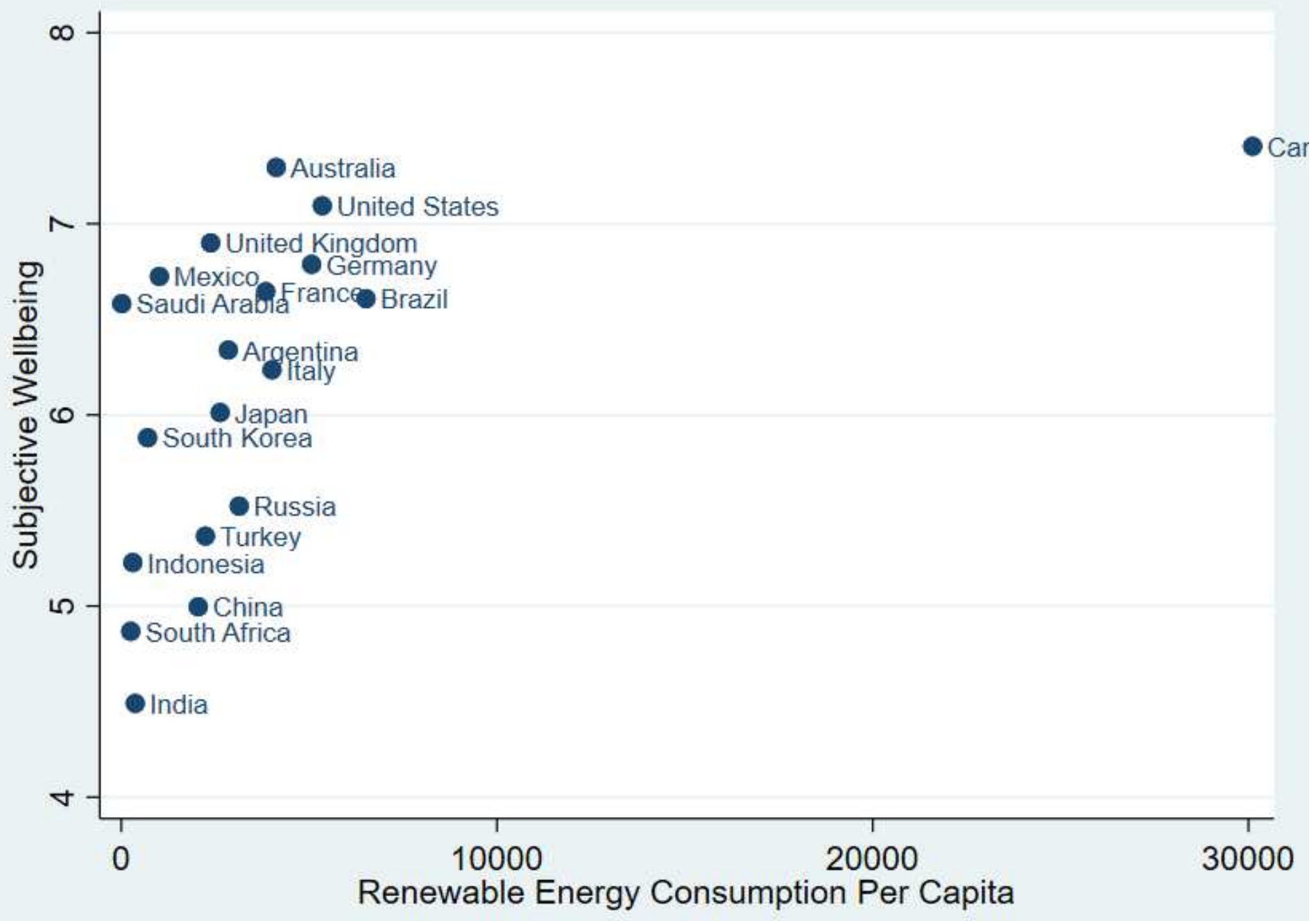

Figure 2

Subjective Wellbeing and REC 


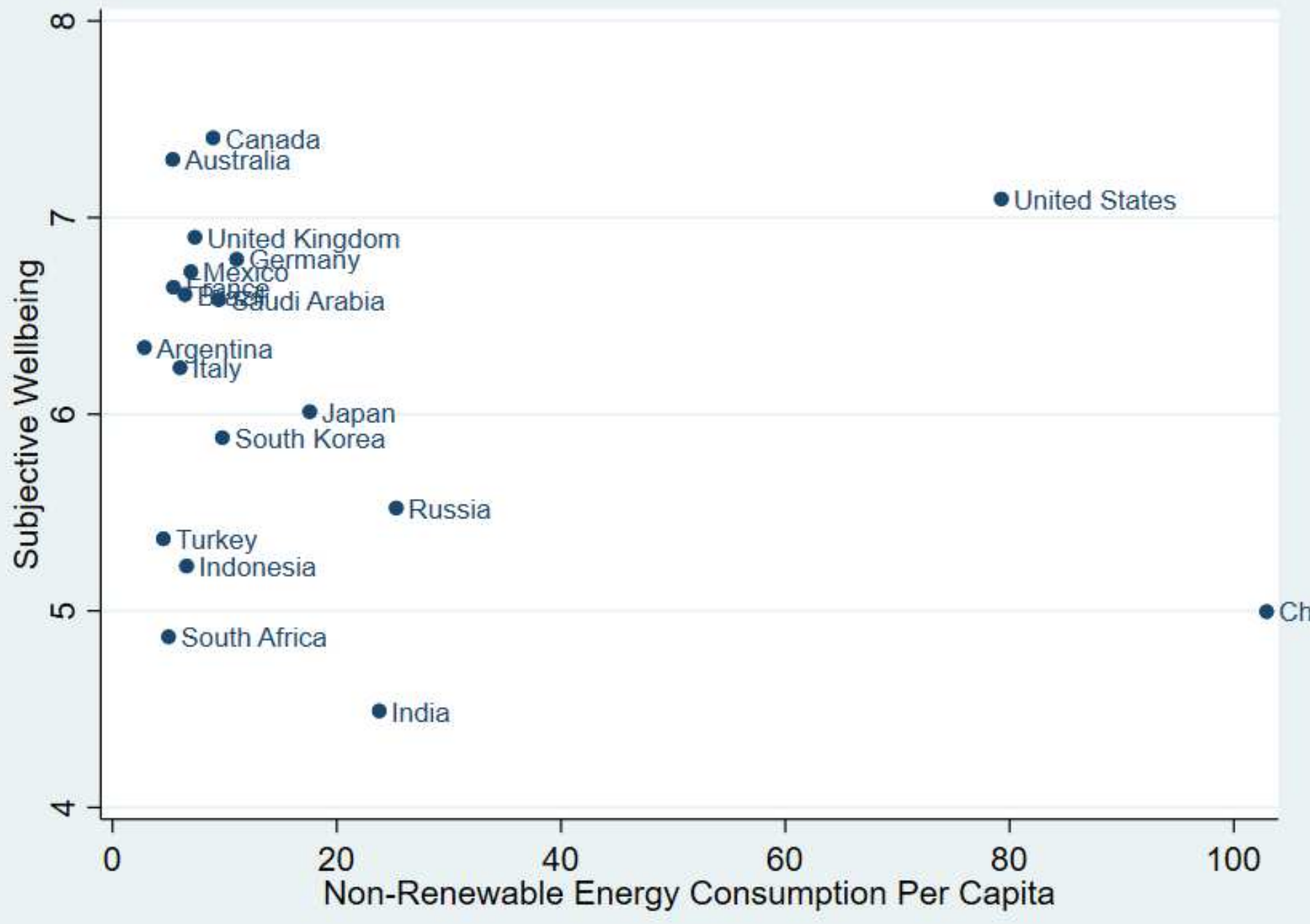

Figure 3

Subjective Wellbeing and NREC 


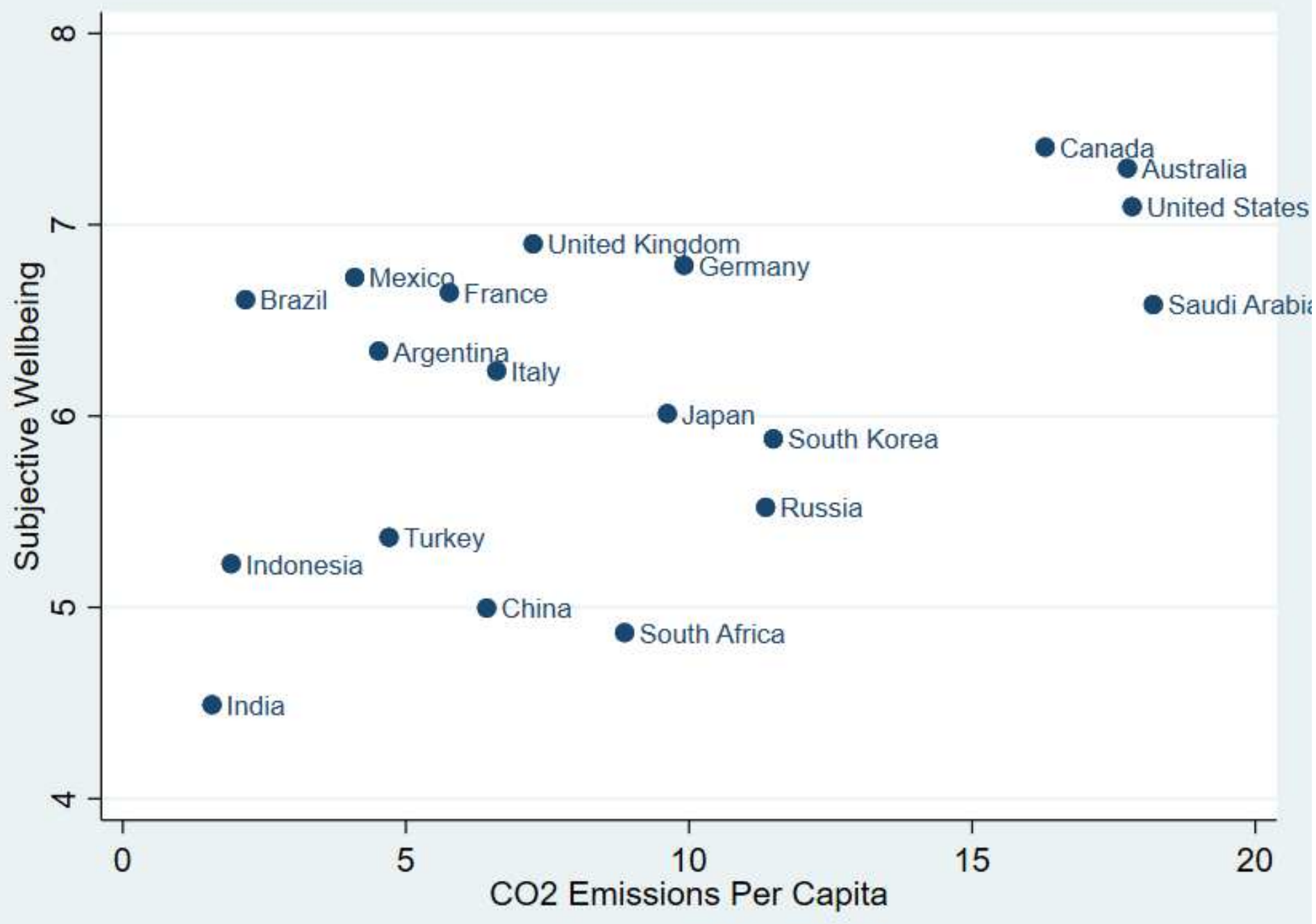

Figure 4

Subjective Wellbeing and CO2 Emissions 


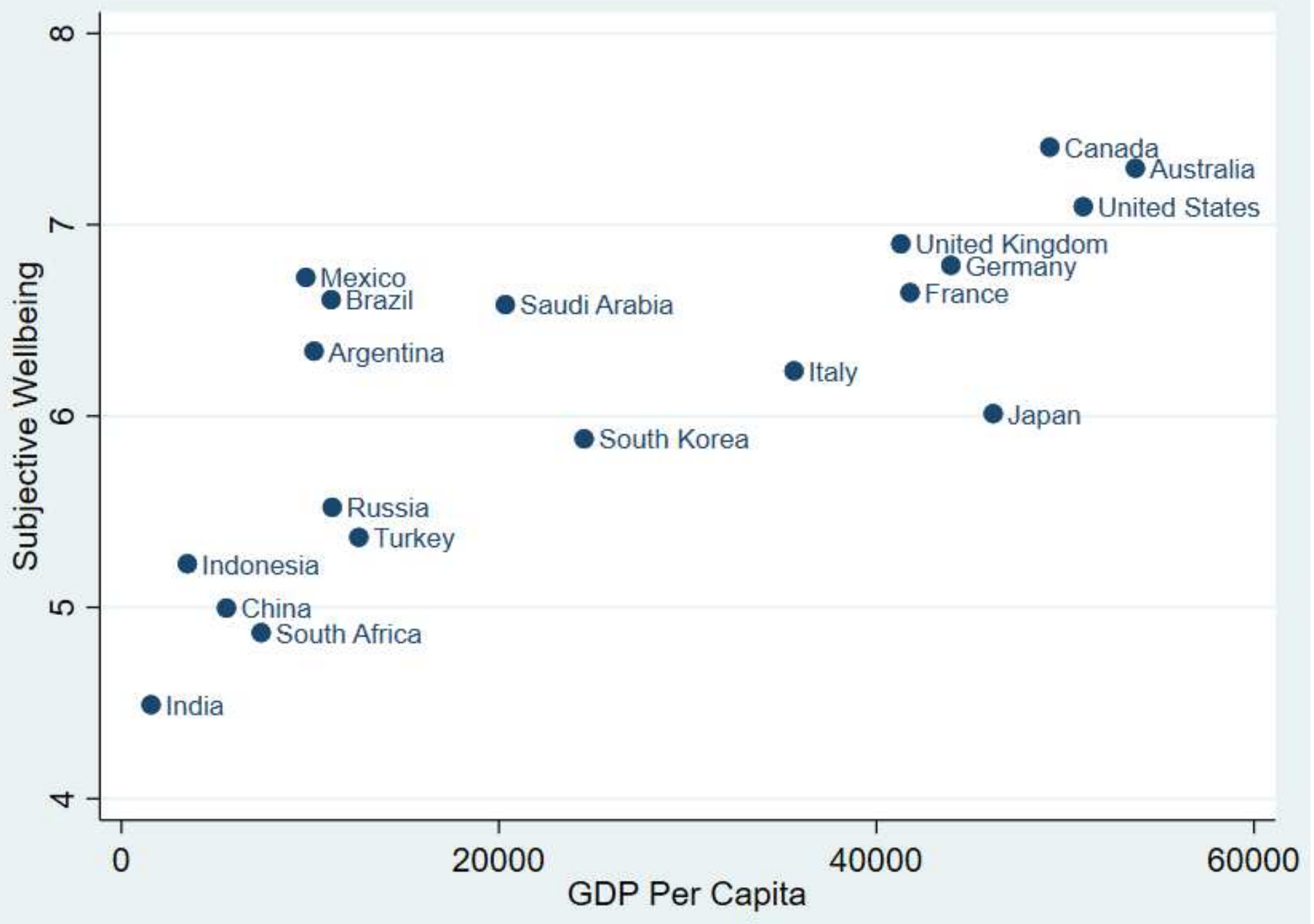

Figure 5

Subjective Wellbeing and GDP Per Capita 


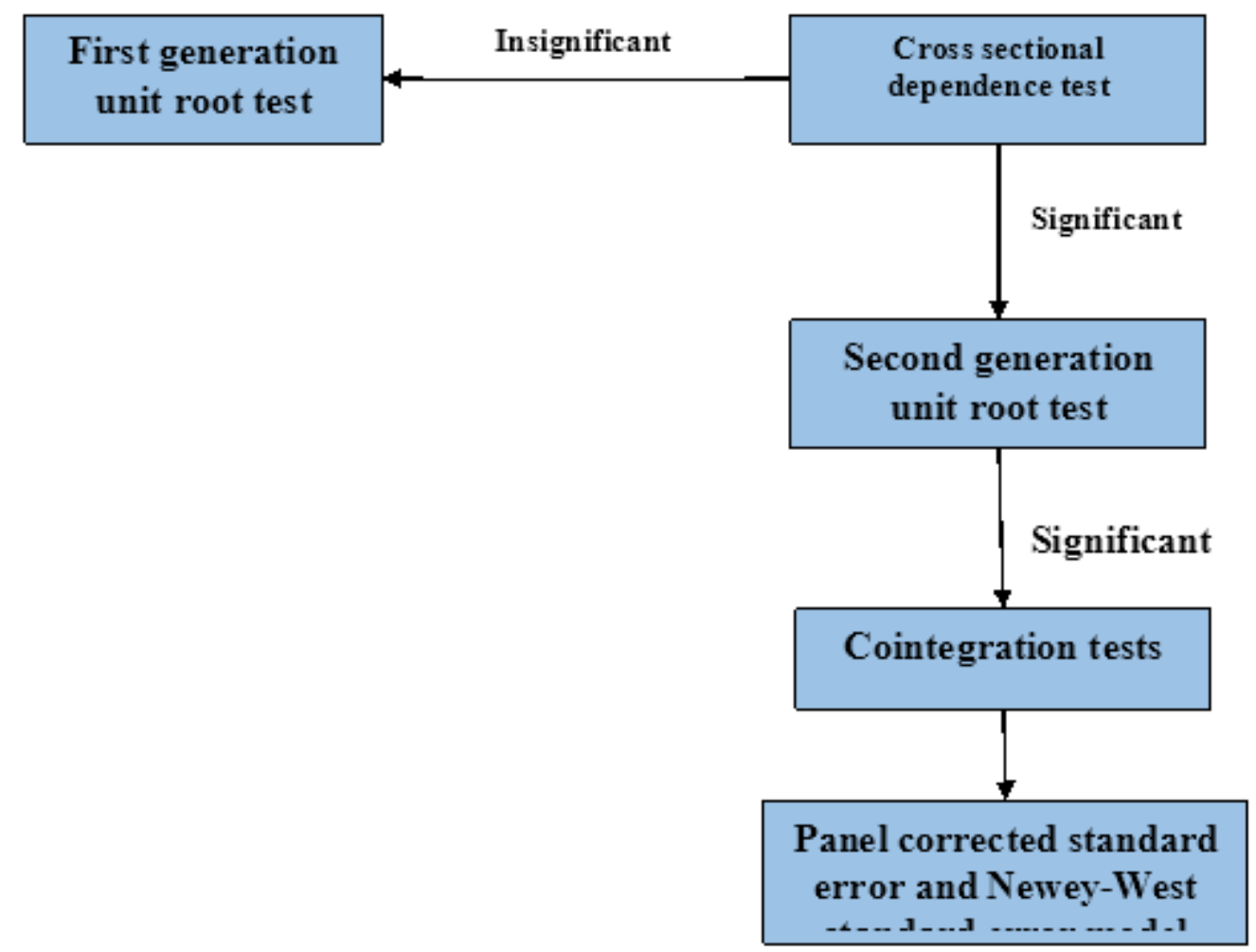

Figure 6

Scheme of Methodology

\section{Renewable Energy}

Consumntion

$+\mathrm{v}$

ely

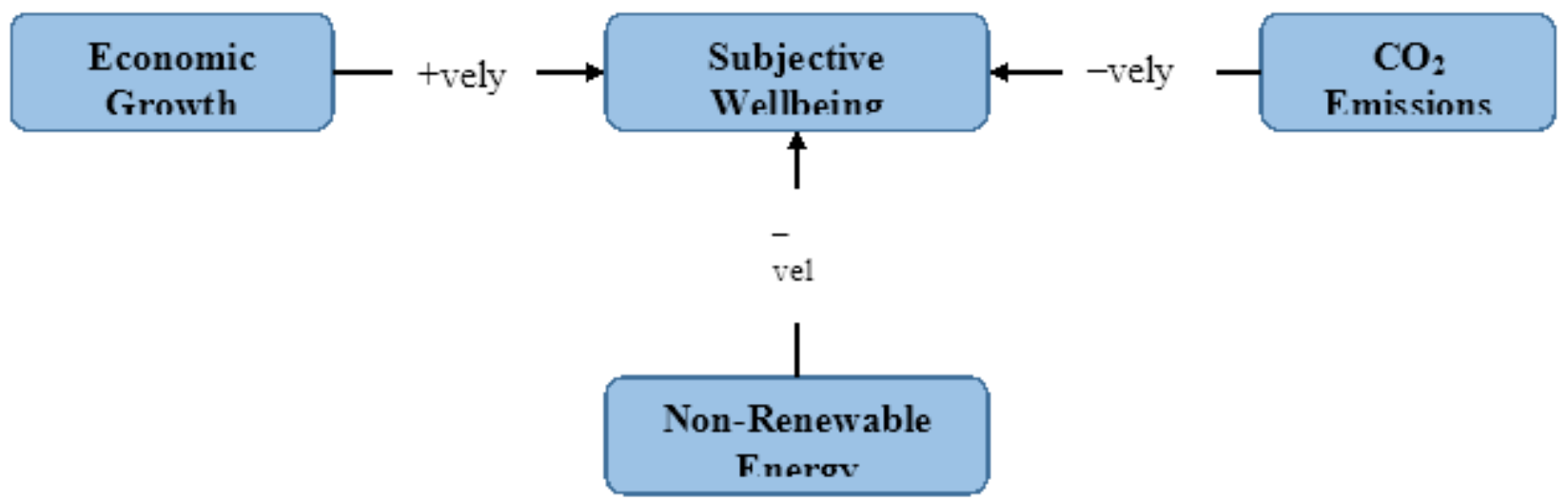

Figure 7

Summary of Findings 